\title{
WPEYW WOJENNYCH WYDARZEŃ DZIEJOWYCH (RES GESTAE) I RELACJI O NICH (HISTORIE RERUM GESTARUM) NA KONDYCJE MATERIALNYCH POZOSTALOŚCI PO TYCH WYDARZENIACH. STUDIUM PRZYPADKU NA TEMAT DZIEDZICTWA KONFLIKTÓW ZBROJNYCH JAKO WYZWANIA POZNAWCZEGO I SPOLECZNEGO
}

\author{
INFLUENCE OF THE MILITARY HISTORICAL EVENTS \\ (RES GESTAE) AND RELATIONS ABOUT THEM \\ (HISTORIES RERUM GESTARUM) ON THE CONDITION \\ OF MATERIAL REMAINS OF THESE EVENTS. \\ CASE STUDY OF THE HERITAGE OF ARMED CONFLICTS \\ AS A COGNITIVE AND SOCIAL CHALLENGE
}

\author{
Anna Izabella Zalewska \\ https://orcid.org/0000-0003-4728-2757 \\ Instytut Archeologii, Instytut Historii, Uniwersytet Marii Curie-Skłodowskiej \\ Plac Marii Curie-Skłodowskiej 4, 20-031 Lublin \\ azalew@op.pl \\ Dorota Cyngot \\ https://orcid.org/0000-0001-7461-5807 \\ Instytut Archeologii i Etnologii Polskiej Akademii Nauk, al. Solidarności 105 \\ 00-538 Warszawa \\ dorota@iaepan.edu.pl
}

ABSTRACT: In the article we consider the relationship between the poor condition of material remains of the Great War on one of the former Eastern Front's battlefield's in the Rawka and Bzura region with the long term attitudes of the local population towards the soldiers of Russian and German armies, fighting and killed there. For this purpose, we have analyzed written sources and witnesses accounts, as well as 
artifacts from archaeological research. We assume that recognizing situation of the local population during the events of 1914-1915 and after the war may bring us closer to answering the questions posed herein. Thus, we suppose, that loss of property, extremely difficult conditions of everyday life, illnesses and suffering, fear of military authorities and soldiers, of epidemic factors and infectious diseases, death of loved ones also those enlisted in the armies of the occupiers - these types of traumatic experiences - conditioned the attitude of the local population towards soldiers of the Great War. Some lasting consequences of this can be observed till today - in the form of fading traces of the material heritage of the Great War. Focusing on the material and discursive dimensions, we analyze the relationships between the primary (res gestae) and consequential/secondary processes (rerum gestarum histories and narrations) and observe a kind of causative "breaking the continuity" between them. Using the methods of historical archaeology, archaeology of recent past, memory studies, history etc., creates interesting, but so far poorly used, research possibilities. Most importantly, it can contribute to shaping attitudes characterized by historical and archaeological sensitivity and the will to understand the value of a difficult heritage (including resting places of fallen soldiers) and to prompt active care for it.

KEY WORDS: attitudes of local people towards the wars' remains, WWI soldiers, cemeteries and graves; material expressions of war and post-war events; res gestae and historia rerum gestarum, contemporary archaeology, World War I, Central Poland

Omawiane w niniejszym artykule problemy odnoszą się do obszaru na Równinie Łowicko-Błońskiej, wzdłuż rzek Bzury i Rawki. Arena zdarzeń, na której kształtowały się badane przez nas relacje i ślady z domeny kontekstu pierwotnego, to odcinek linii działań wojennych między Sochaczewem na północy a Skierniewicami na południu, od Łowicza na zachodzie po Wiskitki i Żyrardów na wschodzie (ryc. 1).

Obszar ten stanowił ważną część frontu wschodniego Wielkiej Wojny - był niemal ostatnim elementem linii rosyjskiego systemu umocnień osłaniających Warszawę, wówczas kluczowe miasto tzw. Kraju Nadwiślańskiego pod rosyjskim zaborem (ros. Привислинский край, Priwislinskij kraj). W okresie od grudnia 1914 do lipca 1915 roku przez obszar ten przemieściły się rzesze żołnierzy walczących ze sobą armii Cesarstwa Niemieckiego i Imperium Rosyjskiego. W obydwu tych armiach byli Polacy z terenów zaboru rosyjskiego i pruskiego. Wielu z nich poległo.

Mimo dużej roli, jaką ten rejon frontu wschodniego odegrał w początkowej fazie Wielkiej Wojny, wiedza o specyfice tamtych wydarzeń wciąż wymaga poszerzenia i doprecyzowania. Dotyczy to luk w stanie wiedzy na temat frontu wschodniego, zarówno w historiografii - polskiej i europejskiej, jak też w wiedzy potocznej. Powyższa diagnoza skłania do zadania pytania, dlaczego tak nikłe jest zainteresowanie wydarzeniami wojennymi i materialnymi śladami tych wydarzeń, których transnarodowe znaczenie dalece wykracza ponad przeciętną (uzasadnienie tej tezy por. Zalewska, 2013, 2016, 2017).

Celem artykułu jest możliwie kompleksowe naszkicowanie uwarunkowań, które zdeterminowały współczesną złą kondycję dziedzictwa materialnego I wojny światowej wybranego odcinka frontu wschodniego na terenie dzisiejszej centralnej Polski. Mówiąc językiem teorii, do podjęcia próby zrozumienia przyczyn aktualnego stanu rzeczy, w tym sposobów wartościowania śladów Wielkiej Wojny, skłoniła nas obserwacja procesu swoistego „zerwania ciągłości” między światem przeszłej 


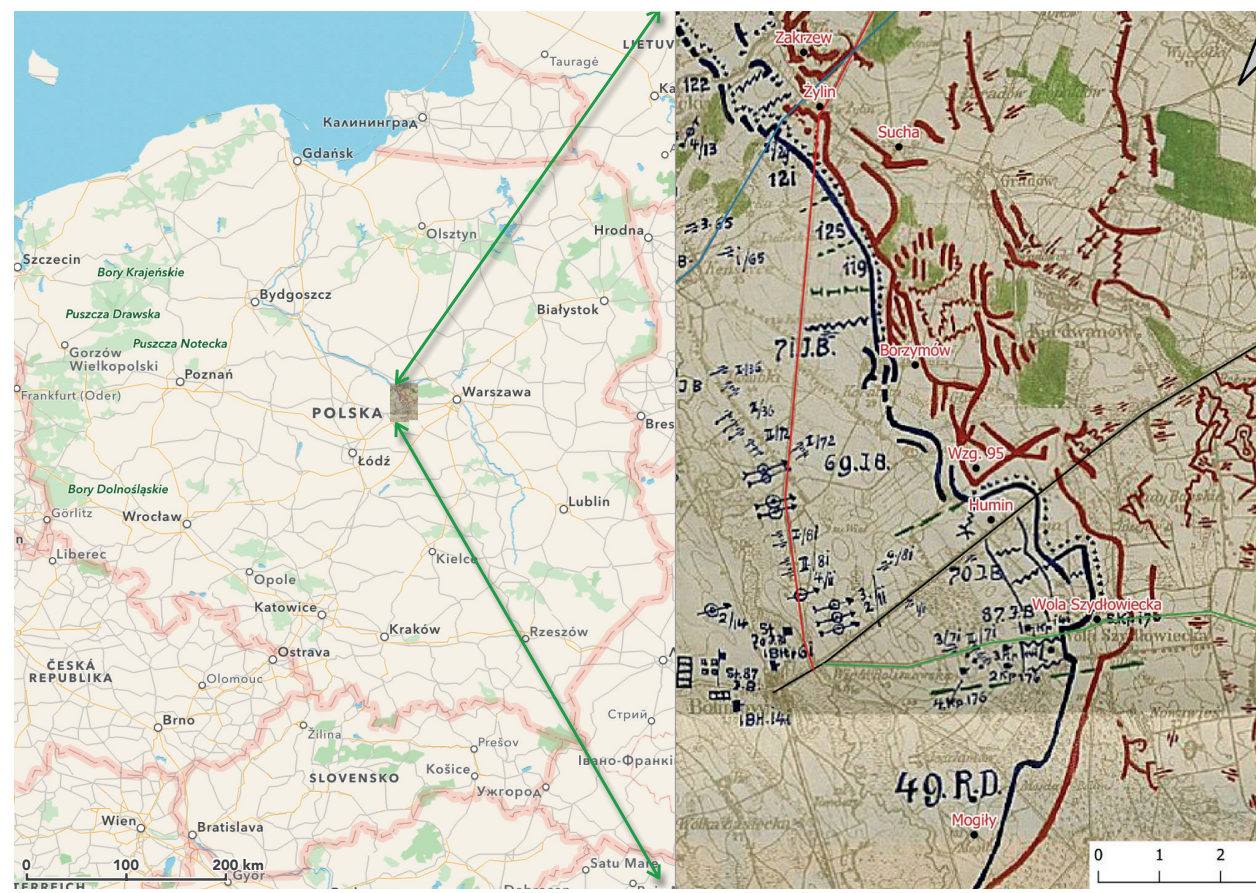

Ryc. 1. Lokalizacja obszaru, na którym kształtowały się omawiane w tym artykule postawy wobec żołnierzy Wielkiej Wojny oraz ich długoterminowe następstwa: woj. mazowieckie i woj. łódzkie, gminy Bolimów, Nieborów, Nowa Sucha, Wiskitki, Łowicz (makieta mapy Apple Inc.; źródło mapy historycznej: HStAS M33/2 Bu 89; Kriegsakten vom 1. - 28.02.1915, s. 218) (oprac. A. Zalewska, J. Czarnecki, G. Kiarszys)

Fig. 1. Location of the area where the attitudes towards the soldiers of the Great War discussed in this article and their long-term consequences took place: Masovian and Łódź voivodeships, municipalities Bolimów, Nieborów, Nowa Sucha, Wiskitki, Łowicz (source: Mockup map by Apple Inc. used as the background; historical map source: HStAS M33/2 Bu89; Kriegsakten vom 1. - 28.2.1915, p. 218) (graphic design by A. Zalewska, J. Czarnecki, G. Kiarszys)

rzeczywistości (tj. obiektywnie zaistniałymi faktami i zdarzeniami - res gestae) a światem wiedzy i pamięci ( $\mathrm{tj}$. reprezentacjami, w tym opisami tych faktów i zdarzeń ujmowanych w ciągi przyczynowo-skutkowe oraz naukowymi opracowaniami na ich temat lub dotyczącymi materialnych po nich śladów - historia rerum gestarum). Zerwanie to nastąpiło na przestrzeni stulecia.

Śledzenie zależności między polem wydarzeń dziejowych (res gestae) a polem relacji o nich (historia rerum gestarum) w odniesieniu do wydarzeń z nieodległej przeszłości z wykorzystaniem metod archeologii historycznej, archeologii współczesnych konfliktów zbrojnych, pamięcioznawstwa, historii itd. stwarza ciekawe, dotychczas słabo wykorzystywane możliwości badawcze.

Pozostałości materialne działań wojennych 1914-1915 z frontu wschodniego tylko pozornie cechują się stosunkowo prostymi do rozpoznania, czytelnymi kontekstami 
funkcjonalnymi. Stanowią one elementy powszechnej, aczkolwiek rozproszonej wiedzy pozaźródłowej, dotyczącej na przykład użytkowanych w owym czasie drobnych przedmiotów czy sposobów konstruowania obiektów o charakterze militarnym, ale także krajobrazowych determinant zastosowania broni masowego rażenia czy grobów i cmentarzy wojennych. Dodatkowy aspekt poznawczy wynika z bliskości czasowej realiów historycznych, czego efektem jest obfitość źródeł materialnych i pisanych oraz możliwość uzyskania źródeł historii mówionej. Sytuacja ta, jak sądzimy, w stopniu nieosiągalnym dla badań nad odległymi epokami umożliwia uchwycenie poprzez konkretne przykłady teoretycznego rozróżnienia: res gestae i historia (narracja o) rerum gestarum, analizowanego zazwyczaj dla wydarzeń i źródeł pisanych dotyczących wczesnego średniowiecza ${ }^{1}$.

W rejonie odcinka frontu wschodniego nad Rawką i Bzurą, w szczególności tzw. przyczółka bolimowskiego ${ }^{2}$ i miast etapowych, np. Łowicza, doświadczonych przez działania wojenne toczące się od jesieni 1914 do lata 1915 roku, pozostały liczne ślady po Wielkiej Wojnie, które nie są otoczone pamięcią i opieką adekwatną do ich wartości naukowej i historycznej. Staramy się dociec, czy za przyczynę ,zerwania ciągłości" między res gestae a historią (narracjami o) rerum gestarum można byłoby uznać uwarunkowania, przejawy i następstwa postaw miejscowej ludności wobec żołnierzy Wielkiej Wojny, w tym wobec poległych żołnierzy, którzy spoczęli na cmentarzach wojennych, a nierzadko także w przypadkowych miejscach w kontekście pola bitwy. Takie postawienie problemu jest następstwem konfrontacji wniosków powstałych w wyniku analiz śladów archeologicznych, w tym zabytków archeologicznych, z wynikami systematycznej kwerendy wybranych zespołów archiwaliów.

W latach 1998-2018 na omawianym obszarze przeprowadzone zostały badania archeologiczne przy użyciu metod nieinwazyjnych (teledetekcyjnych, terenowych poszukiwań powierzchniowych) oraz inwazyjnych (prac wykopaliskowych). Były one ukierunkowane na rozpoznanie obrazów życia i śmierci w okopach Wielkiej Wojny w rejonie Rawki i Bzury, a także materialnych skutków wydarzeń wojennych (por. Zalewska, 2019a; Zalewska, Czarnecki, Kiarszys, 2019). Kwerenda archiwalna ujawniła również liczne informacje i źródła rzucające światło na uwarunkowania społeczne towarzyszące zaistnieniu i trwaniu materialnych pozostałości wojny in situ. Szczególnie przydatne w badaniu aspektów związanych z zaistnieniem, trwaniem w czasie, a następnie z reprezentacjami Wielkiej Wojny w centralnej Polsce były dzienniki cywilnych świadków wydarzeń, świadectwa żołnierzy obu walczących stron, dzienniki bojowe i raporty obydwu armii oraz kroniki pułkowe oddziałów biorących udział

${ }^{1}$ W niniejszym artykule proponujemy wgląd w wydarzenia Wielkiej Wojny z lat 1914-1915 z rejonu Rawki i Bzury i w materialne po nich pozostałości z wykorzystaniem kategorii stosowanych m.in. przez Stanisława Tabaczyńskiego do analiz archeologii średniowiecza, tj. procesu pierwotnego (społeczno-kulturowego), stratyfikacyjnego (źródłotwórczego) i poznawczego (badawczego, źródłoznawczego) (por. Tabaczyński, 1987, s. 13-14, 43-46).

2 Por. uzasadnienie określenia ,przyczółek bolimowski” i jego delimitacji oraz opis przebiegu wydarzeń w: Zalewska, Czarnecki, 2019, s. 28 i n. 
w walkach na będącym tu przedmiotem badań obszarze. Istotne też okazały się archiwalia administracji publicznej różnych szczebli, przede wszystkim gminne ${ }^{3}$.

Z kolei w roku 2020 zainicjowane zostały działania ukierunkowane na ochronę zabytków archeologicznych będących materialnymi pozostałościami Wielkiej Wojny, które zostały rozpoznane na Równinie Łowicko-Błońskiej w latach 1998-2018. Na działania te składają się studia nad odnoszącymi się do wydarzeń 1914-1915 różnego typu rodzajami danych, zastanych i wywołanych. Stanowią one element projektu pt. „Archeologia Frontu Wschodniego Wielkiej Wojny i dziedzictwo konfliktów zbrojnych jako wyzwanie poznawcze, społeczne i konserwatorskie (AFW)", którego realizacja nasunęła wiele kolejnych pytań, np.:

- Przez jakiego rodzaju badania i interpretacje archeologia może przyczyniać się do pogłębienia zrozumienia procesu wtórnego (depozycyjnego, stratyfikacyjnego) oraz pochodnych w stosunku do niego procesów: badawczego (poznawczego) i prospołecznego, odnoszących się w tym przypadku do frontu wschodniego Wielkiej Wojny, aby mogły się one przyczynić do ochrony dziedzictwa Wielkiej Wojny?

- Jakie czynniki warto uznać za kluczowe w kształtowaniu - dawniej i współcześnie - postaw miejscowej ludności cywilnej wobec żołnierzy walczących w rejonie Bzury i Rawki?

- Co przyczyniło się do współczesnej kondycji materialnej i symbolicznej miejsc spoczynku żołnierzy poległych w trakcie działań wojennych 1914-1915 na odcinku między Sochaczewem a Skierniewicami?

- Czy odpowiedzi na powyższe pytania pomocne są w rozumieniu relacji między przeszłymi uwarunkowaniami społecznymi a współczesną kondycją dziedzictwa Wielkiej Wojny w centralnej Polsce, co na poziomie teoretycznym przejawiałoby się jako relacja między res gestae a historią (narracją o) rerum gestarum?

Na pytania te nie znalazłyśmy zadowalających odpowiedzi w zastanej literaturze przedmiotu. Stąd takie, a nie inne ukierunkowanie badań.

Przełożenie pierwotnego procesu (res gestae) na wymiar materialny i dyskursywny (narracje o rerum gestarum) analizujemy jako relację między dwoma różnymi porządkami ontologicznymi (por. uwagi na ten temat: Zalewska, 2009). Bardzo pomocne okazały się przy tym wskazówki metodologiczne Stanisława Tabaczyńskiego, który podkreślał, że:

dostrzeganie materialnych wymiarów kultury - obok naturalnych ograniczeń - przyczynia się też do pełniejszego rozumienia historii zarówno jako odpowiednika dziejów, jak i w znaczeniu relacji o tych dziejach. Historia rerum gestarum może być dzięki rosnącemu wkładowi badań archeologicznych budowana nie tylko na podstawie przekazów pisanych lub tradycji, lecz także na podstawie rzeczowych odpowiedników kultury, biologicznych pozostałości samego człowieka, danych dotyczących środowiska przyrodniczego i wszelkich innych świadectw obecności i działania grup ludzkich.

\footnotetext{
${ }^{3}$ Vide wykaz dokumentów archiwalnych i źródeł w Bibliografii.
} 
Ponadto, w świetle opinii Profesora, właśnie w związku z tym „,archeologia coraz bardziej ugruntowuje swoje miejsce wśród nauk historycznych, nauk o człowieku i społeczeństwie" (Tabaczyński, 1994, s. 8).

Korzystałyśmy przy tym m.in. ze wskazówek metodologicznych Stanisława Tabaczyńskiego, a w szczególności z poczynionych przez niego uwag na temat procesów pierwotnego i pochodnych, do których zawsze odnosi się archeolog, choć nie zawsze je wyróżnia explicite i analizuje w swych badaniach:

Pierwszy z nich jest procesem pierwotnym [...]. Jest to proces społeczno-kulturowy (proces dziejowy), który stanowi właściwy przedmiot badań i którego dotyczyć mają wydawane przez archeologa orzeczenia. Drugi - to proces źródłotwórczy, czyli proces stratyfikacji wyłączanych z użytkowania społecznego rzeczowych korelatów kultury. [...] Trzeci wreszcie - to proces badawczy obejmujący metody i cały aparat poznawczy, za pomocą których badacz formułuje problemy, stawia kolejne diagnozy, odkrywa, rejestruje oraz analizuje i interpretuje zachowane zespoły zabytkowe. (za: Tabaczyński, 1987, s. 13-14, por. Tabaczyński, 1987, s. 43-46, 86)

W licznych wypowiedziach Profesor Tabaczyński, nawiązując do rozróżnienia stosowanego tradycyjnie przez historyków, określał proces pierwotny mianem res gestae, zaś procesy pochodne ${ }^{4}$ wiązał z relacjami o przeszłości - historią rerum gestarum (por. Topolski, 2016, s. 95-975).

W kontekście problematyki omawianej w tym artykule wyraźne rozróżnianie procesów źródłotwórczego i źródłoznawczego wydaje się konieczne i nieodzowne. Przyczyną jest ścisła zależność między procesem badawczym/źródłoznawczym (czy raczej zdiagnozowanymi przez nas zaniedbaniami w jego polu w odniesieniu do dziedzictwa Wielkiej Wojny w centralnej Polsce) a specyfiką, tempem, konsekwencjami procesów „stratyfikacyjnych”/,podepozycyjnych”6.

Badając proces pierwotny (społeczno-kulturowy), czyli warstwę wydarzeń (res gestae), czynimy to poprzez różnego rodzaju źródła pisane (historię rerum gestarum) oraz materialne po nich pozostałości (res), aby dołączyć swoją narrację (o res i o rerum gestarum) do wcześniej istniejących lub by zainicjować kolejne etapy powstawania

4 Jako procesy pochodne są tu rozumiane procesy: źródłotwórczy i badawczy. W kanonicznej dla archeologii historycznej pracy Archeologia średniowieczna... proces ,źródłotwórczy”, zapewne omyłkowo, został nazwany ,źródłoznawczym”. Sprawia to wrażenie, że połączone zostały dwa procesy o różnych charakterach/porządkach ontologicznych: „stratyfikacyjny” i ,badawczy” (,drugi proces [AZ \& DC „źródłotwórczy”] ma charakter źródłoznawczy” - por. Tabaczyński, 1987, s. 45). Przy tym chodzi o proces następujący bezpośrednio po pierwotnym, a przed badawczym, określony jako „wtórny”. Za tym, że użycie terminu ,źródłoznawczy” we wspomnianym kontekście było omyłkowe, przemawia to, że proces wtórny jest w tej pracy w innych miejscach określany jako „źródłotwórczy” (Tabaczyński, 1987, s. 13, 86); powinno to rozwiewać wszelkie wątpliwości.

${ }^{5}$ Rozdział VII: Historia jako res gestae i historia jako historia rerum gestarum.

${ }^{6}$ Stanisław Tabaczyński podkreśla trafność terminu ,proces stratyfikacyjny”, przekonując do traktowania „,procesu depozycyjnego” jako „szczególnego aspektu procesu stratyfikacyjnego”, z czym w zupełności się zgadzamy (Tabaczyński, 1987, s. 13-14). 
historii rerum gestarum. Łącząc w ciągi przyczyn i skutków naszą wiedzę i nasze wyobrażenia o przeszłych wydarzeniach, uczestniczących w nich ludziach i używanych przez nich w trakcie tych wydarzeń przedmiotach, tworzymy kolejne historie i narracje, dążąc do możliwie największej logicznej i faktograficznej spójności oraz czytelności przekazu.

Jak wspomniano na wstępie, analizowane wydarzenia to walki nad Rawką i Bzurą toczone od późnej jesieni 1914 do lata 1915 roku, ich uczestnicy to żołnierze armii Imperium Rosyjskiego i Cesarstwa Niemieckiego oraz miejscowa ludność cywilna, a także włączone w bieg wydarzeń przedmioty i obiekty oraz miejsca. Na opowieść o nich (historia rerum gestarum) składają się nasze wnioski z interakcji ze źródłami pisanymi i ikonograficznymi oraz z odkrytymi i interpretowanymi podczas badań archeologicznych miejscami i rzeczami. Są to głównie militaria (pozostałości broni oraz amunicji strzeleckiej i artyleryjskiej), wyposażenie i rzeczy osobiste żołnierzy, pozostałości fortyfikacji polowych i aprowizacji wojsk, a także pozostałości miejscowej infrastruktury, dobytku ludności zamieszkującej tereny objęte walkami itd. W trakcie wydarzeń wojennych (res gestae) zmieniał się status części uczestników oraz znacznej ilości użytkowanych przez nich w tym czasie przedmiotów i obiektów. Stopniowo odbywało się ich przechodzenie, pojedyncze lub zbiorowe, z warstwy wydarzeniowej $\mathrm{w}$,stan spoczynku”, podleganie depozycji w „kontekście ziemi”. Z czasem zmieniały się także cechy krajobrazu doświadczonego przez te wydarzenia.

\section{RES GESTAE: CZAS I MIEJSCE ZDARZEŃ}

Wydarzenia wojenne w latach 1914-1915, z etapu walk pozycyjnych w centralnej Polsce, to czas grabieży i pożogi oraz traumatycznych doświadczeń mieszkańców ziem zagarniętych przez machinę wojny totalnej, a jednocześnie czas masowej śmierci żołnierzy na froncie wschodnim, podobnie jak na zachodnim. Formowały się wtedy postawy ludności miejscowej zamieszkującej tereny przyfrontowe wobec żołnierzy, których dziesiątki tysięcy wraz z nastaniem wojny zapełniły ulice miast i miasteczek, majątki, wsie, osady itd., również w pasie działań wojennych od Sochaczewa na północy po Skierniewice na południu. W następstwie tych wydarzeń kształtował się także stosunek mieszkańców terenów objętych wojną do masowej śmierci żołnierzy, do wielkiej liczby ciał poległych, nazywanych konsekwentnie w źródłach tego czasu „trupami”, oraz do miejsc ich spoczynku, tj. do wojennych mogił i cmentarzy.

Postępowanie z poległymi było z jednej strony wielkim wyzwaniem logistycznym i praktycznym dla wojskowych służb odpowiedzialnych w każdej z armii za ustanawianie mogił i cmentarzy, $z$ drugiej zaś strony stanowiło także ogromny problem dla ludności zamieszkującej tereny objęte działaniami wojennymi oraz dla administracji cywilnej na tych terenach. Warte podkreślenia jest to, że na wielu obszarach był to żywotny problem długofalowy, trwający jeszcze przez wiele dziesiątków lat po wojnie, który nie został w pełni rozwiązany do dziś - przerastający możliwości organizacyjne i finansowe nie tylko pojedynczych osób cywilnych, ale i władz różnych szczebli. 
Kwestia postaw miejscowej ludności zamieszkującej tereny historycznych pól bitewnych w pewnym sensie zastygła w porządku ontologicznym bliskim res gestae - jako wciąż wynikająca ze specyfiki kontekstu pierwotnego.

\section{HISTORIA (NARRACJE O) RERUM GESTARUM}

O ile proces pierwotny (res gestae) ma charakter ciągły, to w warstwie jego opisu, reprezentacji lub interpretacji można wyodrębnić luki, uskoki czy pominięcia (stanowiące stałą cechę narracji o rerum gestarum) zdarzeń i faktów. Narracja towarzyszy wydarzeniom będącym epizodami procesu pierwotnego. Uczestnicy tego procesu używają materialnych przedmiotów i obiektów (res) oraz dokonują rozmaitych zapisów i rejestracji ikonograficznych z intencją utrwalenia przebiegu wydarzeń bądź bez takiej intencji. To zapisywana na bieżąco historia rerum gestarum.

Ogólnie rzecz ujmując, narracje odnoszące się do Wielkiej Wojny mają różny charakter. Są to publikacje historyczne, dokumenty źródłowe i pamiętnikarskie, regulacje prawne dotyczące grobownictwa wojennego, katalogi cmentarzy wojennych, a także rozmowy/wywiady z osobami zamieszkującymi tereny dotknięte wojną. Ich lektura oraz w pewnej mierze też analiza opracowań badań archeologicznych z tego zakresu skłaniają nas do wyrażenia opinii, że stan wiedzy na temat śladów wydarzeń z lat 1914-1915 na przyczółku bolimowskim, w tym na miejsca spoczynku poległych wówczas żołnierzy oraz stopień ich reprezentacji, ma wpływ na materialną kondycję tych śladów. Jednocześnie kluczowy wpływ miał i niezmiennie ma stosunek do tych śladów miejscowej ludności, lokalnych i centralnych władz oraz wszelkich podmiotów odpowiedzialnych za sprawowanie nad nimi opieki (por. Zalewska i in., 2018a, s. 220). To rozpoznanie jest szczególnie istotne w odniesieniu do miejsc spoczynku poległych żołnierzy. Są one niezmiernie ważną i poruszającą emocjonalnie częścią dziedzictwa kultury. Dyrektywy nakazują, aby groby wojenne były pielęgnowane i otaczane należnym zmarłym szacunkiem i powagą. Bez względu na narodowość i wyznanie żołnierzy w nich pochowanych oraz formacje, w których osoby te służyły. Pozostaje to jednak często martwą literą ${ }^{7}$, choć i na omawianym obszarze zdarzały się chlubne wyjątki, jak np. oddolne działania mieszkańców Bolimowa, Humina, Skierniewic, Wólki Łasieckiej i okolic, którzy identyfikowali i/ lub porządkowali zapomniane cmentarze wojenne i, w miarę możności, dzielili się swoją wiedzą na ich temat (szerzej na ten temat: Zalewska, Cyngot, 2017, s. 131-133, 151; 2019, s. 319-320).

Rozpoznanie zarówno minionych, jak i aktualnych postaw ludności zamieszkującej tereny objęte działaniami Wielkiej Wojny wobec żołnierzy, najpierw walczących tam, a następnie poległych i ,na wieki” tam pozostałych, oraz do miejsc ich spoczynku, postrzegamy w odniesieniu do obszarów znajdujących się w granicach

7 Por. argumenty na temat problematycznej (nie)obecności cmentarzy wojennych w: Zalewska, Kiarszys, 2017, s. 62 i n. oraz Zalewska, Cyngot, 2017. Remedium na brak wiedzy o lokalizacji licznych zapomnianych mogił i cmentarzy wojennych okazała się archeologia, por. Zalewska, Kiarszys, 2019, s. 388 i n. 
Polski jako wciąż niedostateczne ${ }^{8}$. Ponieważ zagadnienia te nie były w zasługującym na to stopniu przedmiotem uszczegółowionych badań, są trudno uchwytne zarówno z perspektywy historycznej, jak i archeologicznej. Docierałyśmy do nich przez dane archiwalne oraz dokumentując obecną kondycję materialnego dziedzictwa Wielkiej Wojny w rejonie konkretnego historycznego pola bitwy (postrzeganego przez badania śladów walk z wykorzystaniem metod archeologicznych oraz historycznych i antropologicznych).

Aktualnie próbujemy znaleźć wspólne, zazębiające się i powiązane między sobą elementy między, najczęściej fragmentarycznymi, informacjami wyłaniającymi się z dokumentów archiwalnych i dzienników czasu wojny a reprezentacją przeszłych wydarzeń (materialną i dyskursywną) tworzoną we współczesności, tj. historią (narracją o) rerum gestarum, pamięcią i wyobrażeniami o nich - od zakończenia działań wojennych do dzisiaj. Towarzyszy nam nadzieja, że rozpoznanie i zbadanie, nawet fragmentaryczne, tych „powiązań” przyczyni się do ochrony zabytków archeologicznych, ruchomych oraz nieruchomych, które zostały zinterpretowane w procesie badań przeprowadzonych w latach 1998-2018 jako ślady działań wojennych z lat 1914-1915 w centralnej Polsce. Postrzegamy je także jako użyteczne przy wypracowywaniu, na podstawie konkretnej grupy znalezisk i zabytków ruchomych (ponad $20000)$ oraz nieruchomych $\left(250 \mathrm{~km}^{2}\right)$ z czasów I wojny światowej, propozycji klucza interpretacyjnego, który byłby potencjalnie pomocny w waloryzowaniu, kategoryzowaniu, konserwacji pozostałości I wojny światowej.

$\mathrm{W}$ proces badawczy angażujemy zapisy dokonywane podczas dziania się wydarzeń - to dzienniki, kroniki, korespondencja, a także obfitość pism urzędowych administracji wojskowej i cywilnej różnego szczebla - spośród których tylko część powstawała z myślą o utrwaleniu przebiegu wydarzeń, natomiast wiele miało charakter użytkowy. Ponadto stan spraw ilustruje znaczna ilość fotografii, rysunków, map i szkiców wojskowych. Szczególnie ciekawym przypadkiem historii rerum gestarum są notatki wyprzedzające bieg wydarzeń albo czasem nawet wpływające na ich przebieg - rozkazy wojskowe, plany strategiczne, zarządzenia administracyjne. Pozwala to śledzić wydarzenia nie tylko od strony przyczyn i skutków, ale niekiedy także intencje i czynne sprawstwo aktorów wydarzeń.

\section{POSTAWY MIEJSCOWEJ LUDNOŚCI WOBEC ŻOLNIERZY WIELKIEJ WOJNY W DOBIE WOJNY W ŚWIETLE DOKUMENTÓW ARCHIWALNYCH}

$\mathrm{Na}$ to jak ludność cywilna odnosiła się do żołnierzy obu armii walczących na jej ziemiach - rosyjskiej i niemieckiej - oraz do poległych w toku działań wojennych,

\footnotetext{
${ }^{8}$ Choć i na tym polu poczyniono już ważne badania, zwłaszcza dla potencjalnych studiów komparatystycznych dotyczących omawianego tu zagadnienia, np. Borzyszkowski, Olbracht-Prądzyński, 1996, s. 7-25; Ogórek, 2018.
} 
a z czasem także do miejsc ich spoczynku, miały wpływ liczne czynniki i okoliczności, często nieoczywiste i trudne do uchwycenia. Stosunek ten przejawiał się w różnych formach, z których nie wszystkie pozostawiły ślady materialne lub zostały odnotowane w archiwaliach.

Dzięki aktom gminy Żyrardów z lat 1914-1915, które przetrwały w zasobach Archiwum w Grodzisku Mazowieckim (oddział Archiwum Państwowego w Warszawie), a powstały w kancelariach warszawskiej guberni, tzw. Kraju Nadwiślańskiego, pod zarządem władz rosyjskich, można śledzić przebieg przygotowań administracji rosyjskiej i władz wojskowych do wojny, a także sposoby organizowania miejsc spoczynku żołnierzy poległych w czasie Wielkiej Wojny na froncie wschodnim od samego jej początku. Są to na przykład: spisy poborowych z 1914 roku (APW OGM, AGŻW nr 1268), sprawy rezerwistów (APW OGM, AGŻW numery 1281, 1319, 1324), powołania do armii (APW OGM, AGŻW nr 1330), ogłaszanie kontrybucji i rekwizycji (APW OGM, AGŻW numery 1323, 1336), nakładanie obowiązkowych prac i posług na rzecz wojska, takich jak dostarczanie podwód i budowa umocnień (APW OGM, AGŻW nr 1326). Nieco późniejszy okres, od lata 1915 roku, oświetlają przechowywane w Archiwum w Łowiczu (również oddział Archiwum Państwowego w Warszawie) dokumenty powstałe w magistracie tego miasta, zarządzanego wówczas przez wojskowe władze niemieckie. Archiwalia te ukazują „od środka”, jak funkcjonowało podczas I wojny światowej miasto etapowe wojsk niemieckich, jakim stał się Łowicz ${ }^{9}$. Informują one o stacjonowaniu wojsk niemieckich na terenie Łowicza, w tym zajmowaniu przez żołnierzy prywatnych domów i ich wyposażenia, sekwestracji materiałów wojennych; wśród tych dokumentów są również skargi mieszkańców na dewastację użytkowanych obiektów i kradzieże (APW OŁ, AMMŁ numery $18,19,26$ ). Jest też wiele zarządzeń w sprawie organizacji handlu, w tym zasady wprowadzania monopolu tytoniowego oraz wielokrotnie aktualizowane wykazy rosnących cen (APW OŁ, AMMŁ nr 24), podawane są reguły racjonowania żywności (APW OŁ, AMMŁ nr 27). Liczne są zgłoszenia reklamowe firm z terenu Cesarstwa Niemieckiego, które oferują swoje wytwory na rzecz wojska oraz listy przewozowe tych produktów do Łowicza (APW OŁ, AMMŁ nr 28).

Dzięki dokumentom z obu oddziałów archiwum - grodziskiego i łowickiego można też próbować bardziej bezpośrednio wniknąć w to, jak kształtowały się nastroje ludności cywilnej na zapleczu frontu. Odnoszą się do tego na przykład dokumenty z 1914 roku zebrane w tematycznej teczce $O$ wojnie z Niemcami i Austria i nastrojach ludności w związu z ta wojna (APW OGM, AGŻW nr 1325) czy informacje o Niemcach i Austriakach (APW OGM, AGŻW numery 1328, 1329), a także osobach wyznania prawosławnego (APW OGM, AGŻW nr 1335) zamieszkałych w gminie Żyrardów. Ludność miejscowa ostrzegana jest w nich przez władze rosyjskie m.in. przed możliwością zatruwania przez Niemców studzien oraz przed ewentualną epidemią cholery; zostaje wydany nakaz przekazywania wszelkiej broni z pobojowisk pod karą śmierci; wójt gminy Żyrardów dostaje polecenie, aby donosił o nastrojach ludności

\footnotetext{
${ }^{9}$ Co oznaczało w praktyce pełnienie funkcji miasta etapowego - zob. m.in. Kaliński, 2013.
} 
W związku z wojną - to tylko kilka detali składających się na obraz życia codziennego mieszkańców strefy przyfrontowej (APW OGM, AGŻW nr 1325).

W odczucia presji, lęku, zagrożenia miejscowej ludności dają nam wąski, ale istotny wgląd, niestety niezbyt liczne dla tego miejsca i czasu, pamiętniki i wspomnienia ${ }^{10}$. Perspektywę mieszkańca Łowicza oddają zapiski historyka-regionalisty Władysława Tarczyńskiego w kronice dziejów tego miasta z pierwszych dziewięciu miesięcy Wielkiej Wojny. Tarczyński (2015) systematycznie, od grudnia 1914 do maja 1915 roku, na bieżąco odnotowywał toczące się w tym rejonie wydarzenia wojenne, oceniał straty materialne i ludzkie, omawiał też nastroje społeczne, do tego dołączał refleksje osobiste. Był on jednym z lepiej zorientowanych w ogólnej sytuacji polskich mieszkańców Łowicza, co zapewne można tłumaczyć tym, że jego zięć (Emil Balcer) został przez niemieckie władze wojenne zmuszony do objęcia stanowiska prezydenta miasta (Wojtylak, 2015, s. 31). Notatki te przedstawiają ogromną wartość dla szeroko pojętej tematyki Wielkiej Wojny jako relacja bezpośredniego świadka wydarzeń na zapleczu frontu (por. egzemplifikacje w: Zalewska, Cyngot, 2017, s. 123; Zalewska i in., 2018a, s. 190; Zalewska, Cyngot, 2019, s. 321).

\section{PROBLEM IDENTYFIKACJI „SWÓJ” - „OBCY”}

Istotnym czynnikiem mającym wpływ na postawy mieszkańców ziem objętych wojną wobec walczących, a następnie poległych żołnierzy, wydaje się rodzaj i stopień identyfikowania się z nimi miejscowej ludności bądź też brak takiej identyfikacji. Rozpoznane przez nas źródła archiwalne jedynie pośrednio ukazują stosunek polskiej ludności cywilnej do żołnierzy obu stron zaangażowanych w konflikt. Można się go domyślać np. na podstawie używanych w dokumentach sformułowań.

Podczas Wielkiej Wojny - gdy Polska nie istniała jako państwo i nie było polskiej armii - mieszkańcy wsi, siół i miasteczek na terenach nad Rawką i Bzurą jako „,swoich" z reguły traktowali żołnierzy armii rosyjskiej. Powoływani byli do niej licznie, z racji bycia w owym czasie obywatelami Cesarstwa Rosyjskiego, ich bracia, synowie i ojcowie, głównie jako zmobilizowani na początku wojny rezerwiści (Kulik, 2012, s. 37-53). Określenia takie jak „,nasi”, „,nasze wojsko” na określenie tego wojska padają w Kronice Łowicza (por. np. Tarczyński, 2015, s. 78, 122). Zdarzali się też w armii rosyjskiej, również w walkach na omawianym odcinku frontu, Polacy w stopniu oficerskim. Nie byli liczni, ale ze względu na elitarny charakter uczelni kształcących

${ }^{10}$ Pewne nadzieje na poszerzenie odnoszącego się do tego problemu zasobu danych źródłowych można pokładać we wciąż niedostatecznie rozpoznanych archiwaliach tego czasu, a wysuwamy tę sugestię w związku z dokumentem odkrytym w archiwum w Grodzisku Mazowieckim. Jest to przesłane na początku wojny, 18 (31) sierpnia 1914 roku, przez Komisarza do Spraw Włościańskich Powiatu Skierniewickiego i Błońskiego polecenie dla wójta gminy Żyrardów, aby donosił Komisarzowi 1 i 15 każdego miesiąca o nastrojach miejscowej ludności w związku z wojną z Niemcami i Austrią (zob. APW OGM, AGŻW nr 1325, k. 56). Niestety w tym zespole archiwaliów nie było odpowiedzi wójta. Można sądzić, że wójtowie innych gmin otrzymali analogiczne polecenia. 
wojskowych armii carskiej i ogromną w nich selekcję (zwłaszcza dla kadetów wyznania katolickiego, a więc głównie narodowości polskiej) - byli wybitni, jak choćby Józef Dowbor-Muśnicki dowodzący 14. Pułkiem Strzelców Syberyjskich w czasie walk w rejonie Rawki i Bzury ${ }^{11}$.

W kontekście badanego obszaru istotne dla kształtowania postaw wobec żołnierzy i miejsc spoczynku poległych jest to, że obecność wojska rosyjskiego stwarzała tu pozór kontynuacji stanu sprzed wojny. Nie jest więc zaskakująca podana w łowickiej kronice uwaga, że podczas trwania operacji warszawsko-dęblińskiej, 25 sierpnia 1914 roku, „nadejście Kozaków wielce uspokoiło mieszkańców Łowicza” (Tarczyński, 2015, s. 66).

Armia niemiecka była natomiast uważana na terenach środkowej Polski za wrogą, mimo że i do niej wcielonych zostało wielu żołnierzy pochodzenia polskiego. Udział mieszkańców dzisiejszych ziem polskich będących poborowymi armii niemieckiej potwierdzają również źródła archeologiczne i antropologiczne (por. Marchewka i in., 2019a, 2019b).

Wkroczenie do Łowicza wojsk niemieckich - zwanych „Prusakami” - poprzedziły opowieści o dokonanych przez nich wcześniej zniszczeniach innych miast. „Uciekający z Kalisza przybyli tu końmi, okropne rzeczy opowiadali o okrucieństwach Prusaków i bombardowaniu miasta; opuścili miasto w tym, jak byli, mienie i wszelkie rzeczy pozostawili w znacznej części bombardowaniem zniszczone" (Tarczyński, 2015, s. 58). Negatywne nastawienie mieszkańców Łowicza ugruntowało się po zaledwie kilkunastu dniach od wkroczenia wojsk niemieckich do miasta 17 grudnia 1914 roku, kiedy to, jak sarkastycznie stwierdził Tarczyński, „rozpoczęło się panowanie przemocy narodu kulturalnego" (Tarczyński, 2015, s. 178).

Wśród poległych żołnierzy obu armii było wielu Polaków. Miejscowa ludność miała tego świadomość i odbierała sytuację wojny bratobójczej jako podwójnie tragiczną (W. T., 1918; Górny, 2014, s. 40). Jak już wspomniano, do wojska rosyjskiego, zwłaszcza do oddziałów rezerwowych, trafiali oni z racji bycia obywatelami Imperium Rosyjskiego, zaś w armii niemieckiej służyło wielu Polaków ze Śląska, Wielkopolski i Pomorza, również w oddziałach, które walczyły nad Rawką i Bzurą. Żołnierzy niemieckich-Polaków wzmiankuje Tarczyński (2015, s. 300), ale nie pogłębia tych obserwacji, pozostając przy stereotypowym, choć potwierdzanym licznymi przykładami obrazie „Prusaków typowych”, a więc „Niemców”.

Zamieszanie pojęciowe wśród miejscowej ludności w kwestii tożsamości żołnierzy potęgowało to, że po stronie niemieckiej, wraz z oddziałami austriackimi, walczyli polscy żołnierze tworzących się wówczas Legionów (Wojtylak, 1997, s. 1 i 4).

${ }^{11}$ Choć akurat Józef Dowbor-Muśnicki został przyjęty z tzw. limitu przysługującego wojskowym wyznania ewangelickiego, z uwagi na to, że liczba Polaków na stanowiskach oficerskich była ograniczona „wakatem katolickim” (Kulik, 2008; zob. Dowbor-Muśnicki, 2013). Kolejny przykład wybitnego Polaka walczącego w carskiej armii na froncie wschodnim przynosi niezwykle ciekawa biografia Władysława Strzemińskiego, oparta na źródłach Rosyjskiego Państwowego Archiwum Wojskowo-Historycznego w Moskwie. Strzemiński w stopniu podporucznika dowodził kompanią saperów w walkach o twierdzę Osowiec (por. Luba, Wawer, 2017). 
Wspominał o tym po latach jeden z Legionistów, Edward Białek, uczestnik potyczki pod Bednarami w gminie Nieborów z czasów operacji warszawsko-dęblińskiej w październiku 1914 roku. Znamienna jest opisana przez niego sytuacja, gdy młodzi legioniści mieli problem z wyjaśnieniem wiejskiej kobiecie, która ich uratowała i ukryła przed żołnierzami rosyjskimi - „Moskalami”, kim są: ,ciekawa była, jakie to wojsko, co po polsku mówi i do tego katoliki. Długo tlumaczyliśmy, nim wyjaśniliśmy jej, że tworzy się wojsko polskie z komendantem Józefem Pilsudskim na czele (Białek, 1939, s. 65).

Bardzo interesujące jest zderzenie idealistycznego spojrzenia tego młodego legionisty, który widzi swoją walkę jako początek wyzwalania Polski przez tworzenie polskiego wojska u boku armii austro-węgierskiej, sprzymierzonej z niemiecką, z jednoznacznie negatywnym obrazem tej formacji, jaki podaje Tarczyński. Postrzega on legionistów jako osoby spaczonych pojęć, bez podstaw narodowych i religijno-moralnych, złych obyczajów, bez zasad, „niebieskie ptaki” niechętne pracy, a w najlepszym razie dla oceny tychże wypadków - ofiary spaczonej idei naganiaczy do „żydowsko-socjalistycznych legionów galicyjskich" (Tarczyński, 2015, s. 344-345). Uważa ich, podobnie jak żołnierzy niemieckich, za najeźdźców (por. Wojtylak, 2015, s. 25).

\section{NIE MA TEGO, CZEGO BY NIE SKRADLI, NIE ZRABOWALI, NIE SPUSTOSZYLI DOSZCZETTIE... PROBLEM NISZCZENIA I RABUNKU MIENIA CYWILNEGO W ŚWIETLE DANYCH ARCHIWALNYCH I ARCHEOLOGICZNYCH}

Negatywne postawy wobec wojsk niemieckich przybierały na sile w miarę upływu czasu, bowiem żołnierze, co dnia dowodząc „panowania przemocy”, nie tylko niszczyli okolice na linii frontu, ale i pustoszyli, zabierając wszystko, co mogło być dla nich przydatne na terenach przyfrontowych. Również Łowicz sprawiał wrażenie przygnębiające:

\footnotetext{
Nie ma drzwi i okien, niekiedy i futryn w mieszkaniach dla nich niezdatnych lub przez nich niezajętych. Na stajnie zamienione są sklepy, warsztaty rzemieślnicze, pokoje piękne i salony; stajniami są szkoły i ochrony, a ławy szkolne, tablice i katedry trzaskają pod toporami „kulturalnych” Niemców; także utensylia szkolne, niemałym trudem i kosztem zdobyte, płoną w ogniu, okna zaś są pozatykane mapami i wzorami rysunków technicznych. Nie wojsko to armii narodu jakiegoś ucywilizowanego, ale horda dzikich zbójów, bandytów, złodziei i hersztów. Nic bowiem nie uszanują, nie ma dla nich nic świętego: kościoła, zabytków historycznych, dzieł sztuki, czci kobiety, ni poszanowania starszego wieku. Nie ma tego, czego by nie skradli, nie zrabowali, nie spustoszyli doszczętnie. (Tarczyński, 2015, s. 194-195)
}

Ten silny przekaz znajduje potwierdzenie i wzmocnienie (!) również w danych archeologicznych. Przykładem ukazującym, w jaki sposób wykorzystywane były przez żołnierzy zrabowane elementy domostw, okiennice, drzwi itd., jest miejsce, w którym 
w toku badań archeologicznych rozpoznano relikty fortyfikacji polowych w Woli Szydłowieckiej, stanowisko APP-19 (ryc. 2). W trakcie realizacji archeologicznych metod inwazyjnych w ramach projektu APP, zbadane zostały wybrane obiekty (w sumie 29), zinterpretowane jako relikty głównej linii obronnej oraz jej zaplecze - newralgiczne punkty przebiegu okopu, jego odnogi i ziemianki (Jakubczak i in., 2017).

Co warte podkreślenia, ślady działań wojennych 1914-1915 na obszarze rozpoznanym archeologicznie w Woli Szydłowieckiej (APP-19) nie manifestują się w ogóle w rzeźbie terenu. Obiekty stanowiące pozostałość intensywnych walk, współcześnie usytuowane w obrębie nieużytków i łąk, nie dawały możliwości zaobserwowania napowierzchniowych form terenowych, zarówno na wizualizacjach stanowiących pochodną numerycznego modelu terenu (NMT), jak i w trakcie prospekcji powierzchniowej. Ponieważ jednak w wyniku kwerend archiwalnych obszar ten został uznany za jedno z pięciu miejsc węzłowych ${ }^{12} \mathrm{i}$ w związku z tym został poddany badaniom archeologicznym, zastosowano tu metody geofizyczne oraz metody inwazyjne (otwarto dwa wykopy - o powierzchni 3,85 i 2,5 ara).

W wyniku badań obiektów zinterpretowanych jako relikty I linii bojowej (obiekt 1) i ,ziemi niczyjej” nie stwierdzono obecności szczątków poległych żołnierzy na przebadanym obszarze, stanowiącym mały wycinek rozległej pozycji będącej częścią ciągnących się kilometrami fortyfikacji polowych. Stwierdzono natomiast liczne występowanie zabytków ruchomych będących pozostałościami działań wojennych. Uwagę badaczy przykuł obiekt 1, a w nim m.in. dość nietypowy zabytek, istotny w kontekście omawianych w niniejszym artykule zagadnień - zgodnie z pierwotną funkcją była to okiennica (zob. ryc. 2).

Obiekt oznaczony nr 1 na stanowisku APP-19, o długości (w obrębie wykopu) $25 \mathrm{~m}$, szerokości $2,20 \mathrm{~m}$ i głębokości $0,75 \mathrm{~m}$, był czytelny na powierzchni niemal całego wykopu. W rzucie poziomym miał nieokreślony, podłużny kształt. Jego wypełnisko stanowił bardzo mocno przemieszany, szary, grafitowy, brunatny i rdzawy piasek z obfitą zawartością materiału zabytkowego, niekiedy silnie rozdrobnionego oraz zerodowanego, związanego z okresem Wielkiej Wojny. Na dnie obiektu wyeksplorowano jedną szeroką deskę i drewnianą okiennicę (ryc. 2 - opis na powiększeniu). Charakter pozostałości okiennicy wskazuje na jej lokalne, cywilne pochodzenie. Wtórnie wykorzystana, najprawdopodobniej posłużyła żołnierzom do ustabilizowania podłoża okopu.

Liczne występowanie zabytków ruchomych powiązanych z codziennością życia w okopach, m.in. zarówno pozostałości amunicji (głównie odłamki), jak i przedmiotów z blachy służących funkcjom bytowym, np. fragmenty puszek żywnościowych i szkło z butelek (co wymaga podkreślenia, o atrybucji zarówno armii rosyjskiej, jak i niemieckiej), nie pozostawia wątpliwości, że depozycji okiennicy na dnie okopu dokonali żołnierze którejś z walczących tu jednostek.

Poszukiwanie odpowiedzi na pytanie, kto konkretnie mógł użytkować ten kompleks obiektów w fazie procesu pierwotnego i depozycyjnego, i jednocześnie, która strona walcząca użyła zrabowanego cywilnego przedmiotu do własnych celów,

${ }^{12}$ Uzasadnienie wytypowania tych miejsc oraz ich charakterystyka z użyciem danych historycznych, archeologicznych i teledetekcyjnych w: Zalewska, Czarnecki, Kiarszys, 2019. 


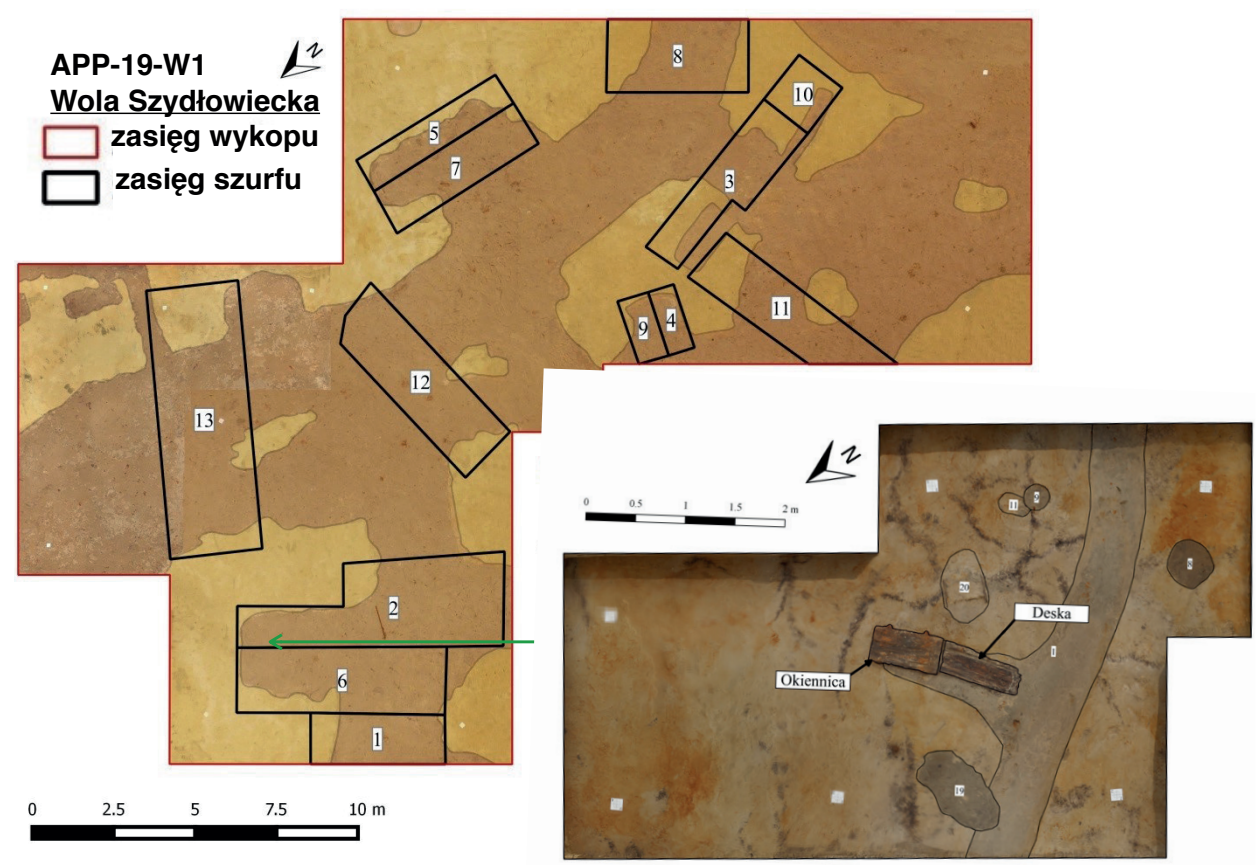

Ryc. 2. Fotoplan wykopu nr 1 na stanowisku nr APP-19 w Woli Szydłowieckiej (gm. Bolimów, woj. łódzkie), z widocznymi obiektami archeologicznymi, w tym obiektami nr 2 i 6, w których odnaleziono pozostałości okiennicy usytuowanej na dnie okopu, prawdopodobnie w celu stabilizacji gruntu (źródło: dane zebrane w projekcie APP) (oprac. Jakubczak i in., 2017, oprac. graficzne: A. I. Zalewska)

Fig. 2. Photoplan of the archaeological trench No. 1 at the site No. APP-19 in Wola Szydłowiecka (commune of Bolimów, Łódź Voivodeship), with visible archaeological objects, including those marked as No. 2 and 6 where the remains of the shutter located at the bottom of the trench, probably to stabilize the soil, were found (source:

ARM's Data Base, elements of the Report by Jakubczak et al., 2017) (graphic design by A. I. Zalewska)

nie dało jednoznacznych rezultatów. Na podstawie wyników kwerend archiwalnych (z uwzgl. m.in. Gebhardt, 1933, s. 17 i n.; HStAS M33/2 Bu 89; Rohkohl, 1923, s. 63; RGVIA, Ф. 2019 O.1) trudno jednoznacznie wykazać, żołnierze której armii użyli do swych celów tę konkretną okiennicę pochodzącą ze zdewastowanego domu i której ślady zostały rozpoznane archeologicznie.

\section{ŻOLDACY CHOWALI TRUPY BEZ ŻADNEGO DOZORU, BARDZO PLYTKO... PROBLEM EPIDEMIOLOGICZNO-SANITARNY W ŚWIETLE DANYCH ARCHIWALNYCH I ARCHEOLOGICZNYCH}

Kolejny bardzo istotny aspekt codzienności wojny nabierał znaczenia wraz z przedłużającym się zastojem wojsk na froncie pozycyjnym w centralnej Polsce. Było to ciągłe poczucie zagrożenia. Wynikało ono m.in. z pogorszenia się stanu epidemiologiczno-sanitarnego, narastającego w toku walk. Zakończenia działań wojennych po- 
czątkowo spodziewano się nie później niż wiosną 1915 roku, a trwały tu aż po miesiące letnie 1915 roku. Problem zagrożenia epidemią wiązał się ściśle z tysiącami pochowanych poległych, a także z setkami, jeśli nie tysiącami ciał żołnierzy zalegającymi, często w przypadkowych miejscach, w różnym stanie, na powierzchni terenu objętego walkami po odejściu wojsk.

Estymacje strat ludzkich na tym odcinku walk sięgają dziesiątek tysięcy poległych. Dotychczas nie zdołano oszacować z wiarygodnym prawdopodobieństwem całkowitej ich liczby (por. Zalewska, 2013; Kaliński, 2019b). Groźba zarazy dostrzegana przez miejscową ludność była realna i wiązała się z licznymi miejscami spoczynku poległych. Potęgowały te obawy ostrzeżenia przed możliwą epidemią, a nawet przed celowym zatruwaniem studni, kierowane w pierwszych miesiącach wojny, jesienią 1914 roku, przez lokalną administrację rosyjską do wójtów gmin i burmistrzów miast, w tym do burmistrza Żyrardowa ${ }^{13}$.

W Łowiczu strach mieszkańców miasta budziły zachowania wojskowych władz niemieckich, które - przynajmniej w pierwszym okresie po wkroczeniu na ziemie nad Rawką i Bzurą - nie stosowały wobec rannych i poległych szczególnych procedur sanitarnych, nie informowały tamtejszej ludności o miejscach pochówków żołnierzy na terenach zamieszkanych, ani nawet nie nakazywały oznaczania mogił. Już pod koniec stycznia 1915 roku Władysław Tarczyński zapisał w swym dzienniku pierwsze obserwacje odnoszące się do postępowania z poległymi, m.in.:

Niemcy nie tylko na cmentarzu chowają swoich, zmarłych z ran i od chorób zaraźliwych, ale ich grzebią w mieście w ogrodach poza domami, gdzie mają szpitale. [...] Oto tym sposobem, zanieczyściwszy niemal całe miasto, narazili je na wielkie niebezpieczeństwo epidemicznego pomoru, tym bardziej, że żołdacy chowali trupy bez żadnego dozoru, bardzo płytko, a co gorsza, że powierzchnię ziemi równali, przez to ślad świeży zaginie, i nie będzie możności ziemi grubiej nasypać dla zatamowania wyziewów i gazów szkodliwych. (notatka z 30 stycznia 1915 roku; zob. Tarczyński 2015, s. 226-227)

Chowanie poległych bardzo płytko i poza przestrzenią cmentarną poświadczają wyniki badań archeologicznych. Na kilku spośród przebadanych wykopaliskowo stanowisk odnalezione zostały szczątki poległych żołnierzy, potwierdzające przywołany powyżej zapis. Przykładem jest miejsce pochówku żołnierzy armii rosyjskiej w okolicy Bolimowskiej Wsi. Miejsce to zlokalizowano przypadkowo, w toku prac budowlanych przy modernizacji drogi. Ponieważ szczątki ukazały się operatorowi koparki w sytuacji, gdy nieopodal archeolodzy uczestniczący w projekcie APP prowadzili badania zapomnianej nekropolii wojennej (stanowisko APP-16 w Joachimowie Mogiłach), zostali oni wezwani do reaktywnego działania. Część szczątków ludzkich oraz materiału zabytkowego została wyrzucona z ziemi przez koparkę w trakcie prac budowlanych. Po zarejestrowaniu faktu natrafienia na szczątki ludzkie, częściowo zniszczony obiekt eksplorowany był zgodnie z metodyką badań obraną dla projektu APP jako stanowisko APP-15 (ryc. 3), tj. po zarejestrowaniu zastanej sytuacji (vide ryc. 3B) eksplorowano

13 Por. np. pismo Naczelnika Powiatu Błońskiego z 17 (30) września 1914 roku do wójtów gmin tego powiatu, burmistrza Żyrardowa i przedstawicieli innych instytucji (APW OGM, AGŻW nr 1325, k. 5). 

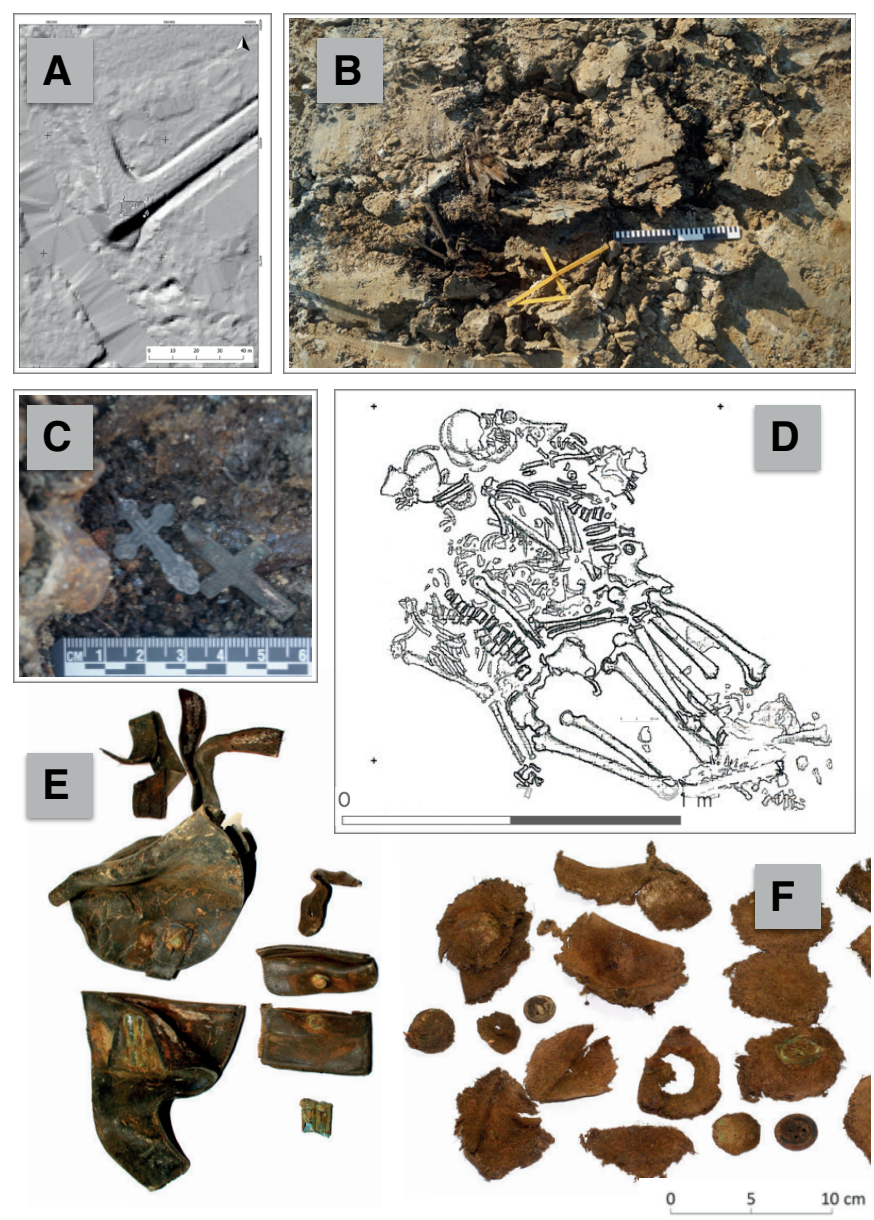

Ryc. 3. Elementy dokumentacji powstałej w toku realizacji badań interwencyjnych w Bolimowskiej Wsi (gm. Bolimów, woj. łódzkie): A - lokalizacja obiektu grobowego odkrytego w trakcie budowlanych prac drogowych, pod skrzyżowaniem dróg na numerycznym modelu terenu NMT; B - sytuacja zastana przez archeologów, fotografia obrazuje szczątki pięciu poległych żołnierzy armii Imperium Rosyjskiego przypadkowo odkryte w trakcie prac drogowych przez koparkę; $\mathrm{C}$ - dewocjonalia in situ zadokumentowane przy szczątkach poległego żołnierza; D - rysunek obrazujący ułożenie szczątków poległych (poziom 2) autorstwa A. Falisa i B. Klęczara; E-F - fotografie znalezisk zadokumentowanych w wyniku badań z udziałem archeologów, pozostałości skórzanej kabury oraz fragmenty umundurowania żołnierskiego (źródło: dane zebrane w projekcie APP) (fot.: A. Falis, T. Myśliwiec i in., 2015, oprac. graficzne: A. I. Zalewska)

Fig. 3. Elements of documentation prepared in the course of the rescue archaeology in Bolimowska Wieś (commune of Bolimów, Łódzkie voivodeship): A - location of a tomb discovered during road construction works, under a road crossing on the digital elevation model (DEM); B - situation found by archaeologists, the photo shows the remains of five fallen soldiers of the Russian Empire's army, accidentally discovered by an excavator during road works; $\mathrm{C}$ - devotional items documented in situ near the remains of the fallen soldier; D - drawing showing the arrangement of the remains of the fallen (level 2) by A. Falis and B. Klęczar; E-F - photographs of finds documented as the result of research with archaeologists: remains of a leather holster and fragments of military uniform (source: Data collected in the APP project) (photos by A. Falis, T. Myśliwiec et al., 2015, graphic design by A. I. Zalewska) 
obiekt/ jamę grobową warstwami naturalnymi przy użyciu sprzętu precyzyjnego (narzędzi sztukatorskich), zaś w miejscach poza obiektem warstwami o miąższości $10 \mathrm{~cm}$ (Falis i in., 2015).

W trakcie całego procesu eksploracji i podejmowania szczątków kostnych oprócz archeologów obecny był na miejscu antropolog. Pozwoliło to na bieżącą ocenę stanu szczątków, a także na wyselekcjonowanie/rozróżnienie szczątków poszczególnych osób, co przy dużym stopniu destrukcji jamy grobowej było znacznym wyzwaniem interpretacyjnym.

Ogólny stan szczątków kostnych określony został w wyniku analiz antropologicznych jako dobry, z wyjątkiem czaszek i kilku kości długich, które uległy zniszczeniu prawdopodobnie przez łyżkę koparki (na co wskazuje analiza przełamów kości). Kości zdiagnozowano jako znacznie rozdrobnione i zdeformowane pośmiertnie. Jednak, mimo silnych uszkodzeń mechanicznych koparką szczątków kostnych i znacznego ich przemieszczenia, opisano układ, specyfikę osobniczą oraz stan zachowania szczątków pięciu pochowanych w płytkim grobie.

W wyniku badań przeprowadzonych z udziałem archeologów i antropolog stwierdzono, że polegli zostali pochowani w pełnym umundurowaniu i z niepełnym wyposażeniem. Odnalezione w jamie grobowej pozostałości umundurowania i wyposażenia jednoznacznie wskazują atrybucję armii Imperium Rosyjskiego. Polegli zostali pochowani bez pasów oraz oporządzenia, które według przepisów powinno być na nie nałożone (tj. bez ładownic lub łopatki saperskiej z pokrowcem). Wyjątek stanowiły szczątki podoficera, któremu pozostawiono pas oficerski z przelotową klamrą i szelkami wzoru z 1912 roku oraz z pustą kaburą wz. 1912 do rewolweru Nagant wz. 1895 (nr inw. 2015-ZS-BW-15-Z63, vide ryc. 3E).

W wyniku badań stwierdzono, że prawdopodobnie w chwili pochówku każdy z poległych miał na sobie buty z cholewami wzoru ogólnowojskowego (sapogi), wełniane spodnie mundurowe wzoru z 1913 roku, onuce lniane lub bawełniane, bieliznę Inianą (zarówno kalesony, jak i koszulę), bluzę mundurową (rubachę) wzoru z roku 1911 (wełnianą) lub z roku 1912 (lniano-bawełnianą), zaś podoficer wełnianą kurtkę mundurową wzoru z roku 1907 (kitel). Ponadto żołnierze byli ubrani w płaszcze sukienne wzoru z roku 1909 lub 1911 (szynele). Wywnioskowano to z poddanych analizie zabytków ruchomych: nr inw. 2015-ZS-BW-15-W1-O1-Z22 oraz 2015-ZS-BW-15-W1-O1-Z13, vide ryc. 3F. Szczątki wraz z większością przedmiotów wydobytych $\mathrm{z}$ jamy grobowej, po dokonaniu badań, zostały pochowane na cmentarzu wojennym w Budach Grabskich.

W kontekście niniejszego opracowania istotna jest sama lokalizacja pochówku w bardzo płytkiej jamie. Miąższość zachowanego obiektu wyniosła w najgłębszym miejscu $30 \mathrm{~cm}$. Długość i szerokość jamy wyznaczyły rozmiary skupiska zachowanych szczątków, które przywierały do ścian jamy (wykopanej w glinie o thustej konsystencji) i wynosiły odpowiednio $1,65 \times 1,00 \mathrm{~m}$. Na wypełnisko jamy składał się poza szczątkami ludzkimi i zabytkami ruchomymi powiązanymi z nimi kontekstualnie szarobrązowy, drobnoziarnisty piasek pochodzący prawdopodobnie z górnych partii gleby. 
Na podstawie wyników badań potwierdzających znaczną liczbę poległych należy założyć, że obawa przed epidemią była też obecna wśród żołnierzy. Jednostkowy wgląd w ten rodzaj lęku daje zapiska, którą sporządził szeregowy armii rosyjskiej Andriej Kuzniecow, żołnierz 49. Syberyjskiego Pułku Strzeleckiego, autor pamiętnika o walkach nad Rawką i Bzurą. W zapisie z dnia 15 (28) stycznia 1915 roku $^{14}$ zarejestrował on, że prowadzone były wówczas obserwacje stanu zagrożenia, skutkujące tym, że w niektórych studniach lekarze znajdowali „zarazę” i wówczas „bez zastanawiania się” kazali je zamykać (por. Zalewska, Cyngot, 2017, s. 136, za: Kuzniecow, 1915).

Po stronie frontowego zaplecza armii rosyjskiej również poza linią frontu stosowano procedury mające zapobiegać rozprzestrzenianiu się epidemii. W jednym z pism urzędowych, wystosowanym w Grodzisku 6 (19) stycznia 1915 roku do wójta gminy Żyrardów, zawarta jest prośba o możliwość chowania na miejscowym cmentarzu osób zmarłych z podejrzeniem chorób zakaźnych, w tym cholery (APW OGM, AGŻW nr 1339, k. 2). W nieco późniejszym zarządzeniu wysłanym 26 stycznia (8 lutego) 1915 roku przez warszawskiego gubernatora do naczelnika powiatu błońskiego podane są procedury wymagane w przypadku chowania osoby, której przyczyną śmierci mogła być cholera:

zarządzam bezwzględne zastosowanie się do zasad ustanowionych prawnie, to znaczy dezynfekcji zarówno grobów, jak i zmarłych [...]; całego zmarłego owijać w prześcieradło zmoczone dowolnym roztworem dezynfekcyjnym, np. nieoczyszczonym kwasem karbolowym; wnętrze zaś grobu obsypać chlorkiem, a przy braku tego niegaszonym wapnem lub też wymazać smołą, dziegciem. W przypadku pochówku w specjalnie przeznaczonych miejscach cmentarzy na mogiłach takich zmarłych usypać kopce na 11/2 arszyna ${ }^{15}$ wysokości. (APW OGM, AGŻW nr 1339, k. 15)

Niepokoje te miały szersze tło. Oprócz zatrucia wód podskórnych wydzielinami z rozkładających się ciał obawiano się też rozprzestrzeniania chorób zakaźnych, czego świadectwem są kolejne zapiski Tarczyńskiego:

w dniu 17 bm. lekarze zauważyli u czterech żołnierzy objawy cholery. [...] Wiadomo, że wśród żołnierzy niemieckich już znacznie dawniej pojawiła się cholera i duży procent ich umierało, co jednak utrzymywali w tajemnicy, tworząc szpital dla chorych na zaraźliwe choroby i zarządzając energiczne środki zapobiegające. (notatka z 21 lutego 1915 roku; Tarczyński, 2015, s. 267)

${ }^{14} \mathrm{~W}$ niniejszym tekście w przypadku źródeł rosyjskich daty podawane są w obu systemach kalendarzowych. Przeliczenie daty podanej w starym stylu na kalendarz gregoriański wymaga dla okresu 1900-2100 dodania 13 dni.

${ }^{15}$ Arszyn to $0,7112 \mathrm{~m}$ (por. Ihnatowicz, 1967, s. 36, tab. 15), a więc wysokość kopca powinna była osiągnąć ok. $1 \mathrm{~m}(1,0668 \mathrm{~m})$. 
Rozprzestrzenianie się tyfusu wśród żołnierzy potwierdzają zapiski polskich świadków wojny, na przykład notatka Władysława Tarczyńskiego z 26 stycznia 1915 roku, informująca o przywiezieniu do Łowicza z pola walki zarażonych tą chorobą: „Rannych przywieziono mnóstwo, także i chorych na tyfus, dla których jest szpital oddzielny” (Tarczyński, 2015, s. 281).

Cholery i tyfusu, przenoszonych przez wszechobecne w okopach wszy, obawiali się również sami żołnierze. Problem wszy i walki z nimi jest stałym tematem żołnierskiej korespondencji kierowanej do rodzin, pełnej pod tym względem irytacji i swoistego czarnego humoru, jak na przykład w kartce wysłanej 27.04.1915 roku znad Rawki przez Wilhelma Lüdersa, żołnierza 1. Kompanii 22. Rezerwowego Batalionu Strzelców, do siostry: „Nie dość, że prowadzimy wojnę z Rosjanami, to jeszcze musimy walczyć z wszami i pchłami. Rozdrapałem już sobie całe ciało. Tylko nie przesyłajcie mi nic na to robactwo, bo i tak nic nie pomoże" (za: Kaliński, 2019a, s. 304).

\section{KTO SIE DO TEGO ROZPORZAZDZENIA NIE ZASTOSUJE, BĘDIE ZASTRZELONY... REPRESJE STOSOWANE PRZEZ ARMIĘ NIEMIECKĄ WOBEC LUDNOŚCI CYWILNEJ}

Na kształtowanie się postaw miejscowej ludności w stosunku do żołnierzy wpływ miały więc zarówno dokonywane przez nich grabieże, jak i masowość żołnierskiej śmierci, z którą mieszkańcy terenów przyfrontowych mieli na co dzień do czynienia i której towarzyszył lęk przed chorobami zakaźnymi. Obie walczące strony borykały się z problemem chowania wielkiej liczby ciał poległych żołnierzy na wielu odcinkach frontu. Sposoby radzenia sobie z tym były różne.

Przykład znajdujemy w telegramie nr 853, mającym charakter cyrkularza (okólnika), wysłanym przez władze rosyjskie z Warszawy 9 (22) sierpnia 1914 roku o godz. 11.00, informującym o działaniach wojennych w rejonie Gąbina w Prusach Wschodnich (wówczas Gumbinnen, obecnie Gusiew w obwodzie kaliningradzkim). Skierowany był do naczelników urzędów w Żyrardowie, z nakazem przekazania zawartych w nim treści „do oddziałów wojskowych znajdujących się w okolicy, do siedzib urzędów państwowych i do gazet" - a więc do administracji wojskowej i cywilnej oraz ogółu obywateli. Donoszono w nim o pierwszych walkach i przegranej wojsk niemieckich - w sile co najmniej trzech korpusów, przechwyceniu ich broni. Pojawił się też wątek poległych: zapisano, że 8 (21) sierpnia „nieprzyjaciel prosił o rozejm dla zebrania zabitych i rannych, ale mu tego odmówiono" (APW OGM, AGŻW nr 1325, k. 39-40). Trudno dziś odpowiedzieć na pytanie - dlaczego?

Eskalację lęku przed ,trupim jadem” i chorobami zakaźnymi, a pośrednio kształtowanie negatywnych postaw wobec żołnierzy (zwłaszcza niemieckich), potęgowało niedoinformowanie w kwestii liczby poległych. $\mathrm{O}$ unikaniu podawania przez strony walczące wysokości strat, także w trakcie działań wojennych, pisał w swej kronice Władysław Tarczyński. Sądząc z jego zapisków, sytuacja na polu walki wymykała się spod kontroli wojskowych wielokrotnie, zarówno zimą, jak i wiosną 1915 roku: 
Na linii bojowej wielka ilość ciał poległych, już rozkładających się, uniemożliwia wojsku siedzenie w okopach. Dlatego sztab ogłosił żołnierzom, że każdy, kto pójdzie na ochotnika grzebać poległych, dostanie Krzyż Żelazny i 15 dni urlopu. Ochotników nie było. (notatka z 4 maja 1915 roku; Tarczyński, 2015, s. 350)

Podobnych obserwacji jest w Kronice dziejów Łowicza wiele ${ }^{16}$ i nie były to sytuacje odosobnione.

Na kształtowanie się postaw miejscowej ludności wobec poległych żołnierzy i ich pochówków wpływały z pewnością wielkie liczby takich miejsc, pozostałych na terenach pobojowisk po zakończeniu walk nad Rawką i Bzurą w lipcu 1915 roku. Były to i cmentarze wojenne, i naprędce wykopane mogiły tworzone w przypadkowych miejscach, i niepogrzebane, czasem rozproszone szczątki żołnierzy, zwłaszcza na tzw. „ziemi niczyjej”. Stanowiło to duży problem dla ludzi, na których polach te pochówki, pozostające w różnym stanie, się znajdowały.

To jednak wciąż nie wyczerpuje odpowiedzi na pytanie o uwarunkowania, przejawy i następstwa postaw miejscowej ludności wobec żołnierzy Wielkiej Wojny, w tym do żołnierzy, którzy polegli w rejonie Rawki i Bzury. Można byłoby sądzić, że stwierdzana w dokumentach obojętność ludności cywilnej czy też brak dbałości o mogiły wojenne, a nawet ich dewastacje - mimo religijnego nakazu czci dla zmarłych - częściej miały miejsce w stosunku do miejsc spoczynku żołnierzy armii uważanej za wrogą niż za taką, w której służą także „swoi”. Śledzenie poprzez dokumenty archiwalne poszczególnych opisanych tam sytuacji nie pozwala jednak na wysunięcie takiego uogólnienia.

Z dokumentów wynika m.in. negatywny stosunek miejscowej ludności do wojskowych władz niemieckich, które po ustąpieniu administracji rosyjskiej wkroczyły na tereny przez nią opuszczone. Przejawy tej niechęci czytelne są we wszystkich wspomnieniach czasu wojny, czego licznych dowodów w przypadku Łowicza, zajętego przez Niemców już w grudniu 1914 roku, dostarcza cytowana tu wielokrotnie Kronika Władysława Tarczyńskiego. Podobne były zachowania wojsk niemieckich i reakcja na nie ludności miejscowej w innych ośrodkach rejonu nad Rawką i Bzurą. Po wkroczeniu oddziałów wojsk niemieckich do Żyrardowa w lipcu 1915 roku komendant niemiecki ogłosił liczne restrykcje dla mieszkańców miasta, a ich skutkiem były powtarzające się egzekucje ludności cywilnej (Hulka-Laskowski, 1934, s. 185186, zob. szersze omówienie Zalewska i in., 2018b, s. 86-87).

Represje stosowane przez armię niemiecką we wszystkich miastach, które zajmowała, poczynając od całkowicie zniszczonego Kalisza, z którego uciekinierzy już w sierpniu 1914 roku docierali na ziemie nad Rawką i Bzurą, utwierdzały miejscową ludność w negatywnym stosunku do tych wojsk. Do tego dochodziły dokonywane przez żołnierzy rabunki, rekwizycje mieszkań i wszelkich zasobów mieszkańców. Negatywna opinia o wojskach rosyjskich wynikała zaś nie tyle z doznanych z ich strony krzywd, ile z rozczarowania miejscowej ludności faktem dostrzeganej przez

16 Por. Tarczyński, 2015, m.in. s. 229-230, 237, 356. 
nie nieporadności w walce i nieudolności dowództwa, z niezrozumiałego dla mieszkańców tych ziem ustąpienia armii rosyjskiej - bez rozstrzygającej walki, i wreszcie ze stosowania przez wojska rosyjskie przy odwrocie taktyki ,spalonej ziemi” (Washburn, 1915, s. 312 i n.; Hulka-Laskowski, 1934, s. 183-185; Brudek, 2010, s. 72-76). Ludziom pozostały zgliszcza ich domostw i znój zdegradowanej codzienności w zrujnowanym krajobrazie (ryc. 4).

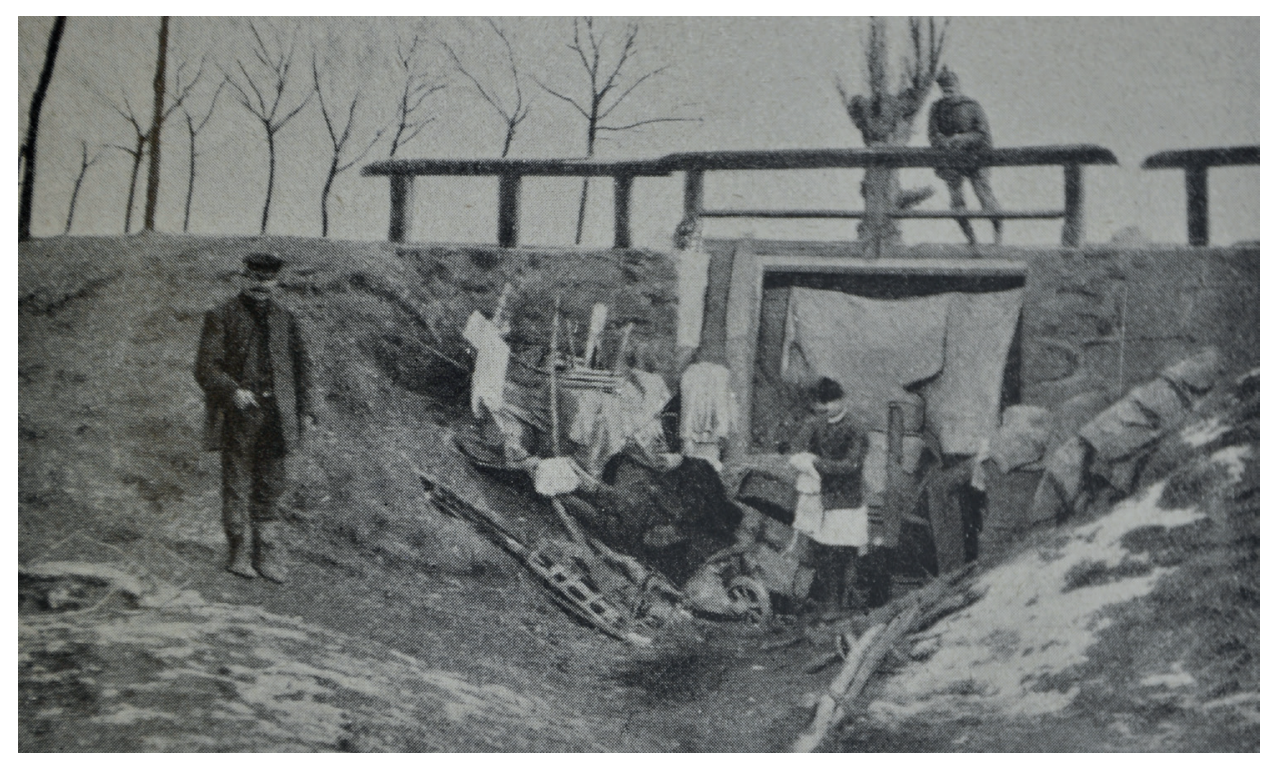

Ryc. 4. Fotografia ukazująca warunki, w jakich przyszło żyć na skutek działań wojennych mieszkańcom rejonu Bzury i Rawki. Domostwo polskiej rodziny w przepuście mostu, rok 1915 (źródło: z prywatnej kolekcji Jacka Czarneckiego)

Fig. 4. A photograph showing the conditions in which the inhabitants of the region over Bzura and Rawka came to live as a result of hostilities. Homestead of a Polish family in a culvert of a bridge, 1915 (source: form the private collection of Jacek Czarnecki)

Wszystko to potęgowało negatywne emocje wobec żołnierzy armii zaborczych, co zapewne znajdowało odzwierciedlenie w stosunku do miejsc spoczynku poległych żołnierzy. Pierwsze oficjalne informacje o problemie ochrony cmentarzy przed dewastacjami pochodzą z czasu Wielkiej Wojny z okupowanego przez Niemców Łowicza. W archiwum miejskim zachowało się ogłoszenie z 13 lipca 1916 roku, w którym ówczesny prezydent miasta podaje do wiadomości, że niszczenie grobów wojskowych i zrywanie z nich kwiatów jest karalne (APW OŁ, AMMŁ nr 32, k. 15). O przypadkach dewastacji bardziej szczegółowo informuje meldunek Komendanta Łowicza skierowany 5 lipca 1916 roku do Magistratu, raportujący uszkodzenie muru cmentarza ewangelickiego. Stworzyło to możliwość przechodzenia przez cmentarz krótszą drogą i powodowało, że miejscowa ludność zrywała kwiaty rosnące na grobach wojskowych. W odpowiedzi na ten meldunek wydane zostało 6 lipca postanowienie 
o surowych karach za taki proceder (APW OŁ, AMMŁ nr 32, k. 19). Pochowani, o których grobach informują wspomniane dokumenty, to z dużym prawdopodobieństwem żołnierze czasu Wielkiej Wojny. Władze niemieckie musiały interweniować w sprawie ochrony ich grobów (por. Zalewska, Cyngot, 2017, s. 136).

\section{EKSHUMACJE ZWLOK I PRZENIESIENIE CMENTARZY UCZYNIĆ NA WLASNY KOSZT... DLUGOTRWALE OBCIĄŻENIA NASTĘPSTWAMI WIELKIEJ WOJNY}

W okresie między wojnami państwo polskie podejmowało akcje inwentaryzacyjne oraz komasacje cmentarzy i mogił wojennych. Powoływano przewidziane do tego typu prac odpowiednie wydziały w urzędach powiatowych. Jednym z ich zadań było prowadzenie rejestrów cmentarzy i pochowanych wojskowych. Zintensyfikowano też działania na rzecz ochrony miejsc spoczynku poległych przed szabrowaniem i zacieraniem ich napowierzchniowych form. Znane są jednak przypadki, gdy władze państwowe nie wspierały ekshumacji terenów pobitewnych, przenosząc obciążenia finansowe i konieczność radzenia sobie z tym problemem na prywatnych właścicieli pól, na których spoczywali pogrzebani żołnierze. Sytuacje takie miały miejsce również na ziemiach nad Rawką i Bzurą.

Możemy tu przywołać tytułem przykładu historię trojga obywateli gminy Bolimów, Witkowskiego, Jagury i Stopczyńskiej, którzy jesienią 1920 i wiosną 1921 roku złożyli wnioski o usunięcie cmentarzy wojennych z ich pól na koszt rządowy, a w lipcu 1922 roku otrzymali z Ministerstwa Spraw Wojskowych pismo z wyrażeniem zgody na przeniesienie tych cmentarzy na najbliższy cmentarz wojskowy, ,jeżeli powyżsi właściciele gruntów zajętych przez cmentarz zechcą ekshumacje zwłok i przeniesienie cmentarzy uczynić na własny koszt, z zachowaniem wszelkich odnośnych zarządzeń i obowiązujących przepisów"17.

Równolegle trwały intensywne prace inwentaryzacyjne realizowane przez stronę niemiecką. Wgląd w ich specyfikę umożliwiają materiały niemieckiego Ministerstwa Spraw Zagranicznych oraz organizacji Volksbund Deutsche Kriegsgräberfürsorge e.V. z lat 1923-1939, odnoszące się do cmentarzy Wielkiej Wojny na terenie pola bitwy nad Rawką i Bzurą (por. Karczewska, 2019). Również te dokumenty przynoszą informacje o nieuporządkowanych mogiłach.

Usuwanie ciał poległych z miejsc użytkowanych gospodarczo (wsie, pola, drogi), ekshumacje, komasacje cmentarzy postępowały niezwykle wolno. Pobojowisko i jego okolice przez całe lata były postrzegane jako ,jedno wielkie cmentarzysko" (por. Zalewska i in., 2018a, 2018b; Zalewska, Cyngot, 2019).

Konieczność kontynuowania starań o rozwiązanie problemów, z jakimi borykała się miejscowa ludność, a które wynikały z masowości żołnierskiej śmierci w latach

17 Zagadnienie to zostało szczegółowo opisane w: Zalewska, Cyngot, 2017, s. 137-149. Archiwalia z zespołu: APW OŁ, AGBol. nr 58, k. 3. 
1914-1915, trwała jeszcze długo po wojnie 20. roku, a także po II wojnie światowej - nie tylko dlatego, że przybyło poległych, ale też dlatego, że tych z tzw. „dawnej wojny", czyli Wielkiej Wojny, pozostało aż tak wielu na omawianym tu terenie. Informacje na ten temat odnaleźć można m.in. w dokumentach z łowickiego oddziału Archiwum Państwowego w Warszawie datowanych na wczesne lata 20. XX w. Na przykład w zawiadomieniu mieszkańca Łowicza skierowanym 21 czerwca 1922 roku do Komendanta Policji z informacją, że rosyjska „bratnia mogiła” z Wielkiej Wojny wykorzystywana jest przez mieszkańców miasta jako pastwisko dla kóz ${ }^{18}$ (por. Zalewska, Cyngot, 2017, s. 137 i n.). W dokumentach tych znaleźć można kolejne potwierdzenie tego, że związek między narodowością poległych żołnierzy i ich przynależnością do którejś z armii a dbałością bądź brakiem dbałości mieszkańców terenów walk o cmentarze wojenne, na których spoczęli, nie był oczywisty (por. opis „,sprawy kóz" wypasanych na cmentarzu, która dobrze wprowadza w temat postaw Polaków, zarówno ludności miejscowej, jak i władz różnego szczebla, wobec cmentarzy i grobów z I wojny światowej).

Jednocześnie jednak po II wojnie zaczęto dość powszechnie postrzegać cmentarze wojenne w centralnej Polsce jako „nie nasze”, ale „niemieckie” cmentarze. W związku z tym w dużym stopniu podlegały one ogólnej polityce wobec wszystkiego, co niemieckie: pozostałości tego rodzaju były likwidowane w sposób mniej lub bardziej otwarty i planowy. Dyrektywa taka pośrednio zawarta została już w jednym z najwcześniejszych zarządzeń organów powojennego państwa i skierowano ją aż do najniższego szczebla administracyjnego - do gmin. W piśmie przesłanym przez Powiatowy Oddział Informacji i Propagandy w Łowiczu do Zarządu Gminy w Bolimowie w dniu 17 lipca 1945 roku, które możemy potraktować jako przykład, czytamy:

Mając na względzie treść okólnika Nr 7 Ministerstwa Informacji i Propagandy, proszę o niezwłoczne sprawdzenie, czy na terenie gminy zostały już usunięte wszelkie napisy w języku niemieckim, na pojazdach mechanicznych, drogowskazach, szyldach ulicznych itp. $[\ldots]$.

W terminie nieprzekraczalnym do dnia 1 sierpnia b.r., wszystkie takie napisy w języku niemieckim winny być bezwzględnie usunięte [...]. W razie napotkania na jakiekolwiek sprzeciwy proszę o nadesłanie wykazu czynników lub instytucji stawiających opór. (APW OŁ, AGBol. nr 186, k. 24)

Z rozmów przeprowadzonych przez nas z mieszkańcami gmin Bolimów i Nowa Sucha (por. Zalewska i in., 2018a) wynika, że to właśnie po drugiej wojnie światowej „przeniesieniu” uległa część cmentarzy, w tym wielu płyt kamiennych z niemieckimi nazwiskami.

${ }^{18}$ Zob. APW OŁ, AMMŁ nr 517, k. 63. Por. też Zalewska, Cyngot, 2017, s. 137. 


\section{FRAGMENTARYCZNOŚĆ OBRAZÓW POSTAW LUDNOŚCI WYŁANIAJĄCA SIĘ Z DOKUMENTÓW CZASU WOJNY I ICH REPREZENTACJE (MATERIALNE I DYSKURSYWNE) WE WSPÓLCZESNOŚCI. PODSUMOWANIE}

Archeolodzy badający materialne ślady wydarzeń, takich jak Wielka Wojna, dla których zachowały się relacje bezpośrednich świadków, mają wyjątkową możliwość wglądu w przebieg procesu pierwotnego poprzez wykorzystanie różnego typu danych niedostępnych badaczom starszych okresów dziejowych. Zyskują wiedzę o przeszłych wydarzeniach, ich uczestnikach, przedmiotach używanych przez nich w trakcie tych wydarzeń, o specyfice miejsc, w których te wydarzenia zachodzą oraz o ich przekształceniach. Wiedza ta pociąga za sobą wyraźne ukierunkowanie ram interpretacyjnych przy budowaniu przez badacza obrazu przeszłych wydarzeń.

Jest to szczególnie skomplikowane w sytuacji, gdy analizowany temat nie przekłada się w sposób oczywisty na wymiar materialny, będący przedmiotem badań archeologicznych. Znaleziska archeologiczne nie zawsze, bowiem można uznać za istotne uzupełnienie opisów wydarzeń z przeszłości (narracji o rerum gestarum), a wydarzenia historyczne (res gestae) nie w każdym wypadku stanowią wytłumaczenie odnajdywanych z udziałem archeologii materialnych pozostałości i ich kontekstów. Poza źródłami materialnymi oraz dostępnymi nam źródłami pisanymi odnoszącymi się do kontekstu pierwotnego (res gestae), musimy więc w procesie interpretacji, wnioskowania i reprezentacji brać pod uwagę także niekompletność wiedzy na temat procesów wtórnych ${ }^{19}$. Tak jest w przypadku będących w tym artykule przedmiotem refleksji postaw ludności cywilnej z rejonu walk nad Rawką i Bzurą wobec żołnierzy i wobec miejsc ich spoczynku.

Naszkicowane powyżej przykłady historii/ narracji, będące wynikiem podjętej próby określenia i wyjaśnienia przyczyn tak złożonego zjawiska, jakim były i są postawy miejscowej ludności wobec żołnierzy - uczestników i sprawców wydarzeń wojennych na ich ziemi, budowane są z wykorzystaniem zarówno znaków, jak i oznak (przejawów) zaczerpniętych z sytuacji jednostkowych, incydentalnych. Uznawane były one jednak (również przez świadków wydarzeń) za zjawiska typowe i w związku z tym można je traktować jako dające wgląd w złożoność tego obrazu. Niektóre spośród tych diagnoz mają charakter uogólnień i noszą cechy stereotypów, m.in. związanych z narodowością żołnierzy bądź miejscowej ludności.

Wszystkie one pośrednio składają się na powody, dla których materialne ślady wojny, w tym miejsca spoczynku poległych żołnierzy (włącznie z większością

19 „Proces wtórny (depozycyjny, stratygraficzny) nazywany jest też źródłotwórczym. Określenie to, używane precyzyjnie, należałoby rozumieć jako nadawane ex post, z pozycji prowadzonych po wydarzeniach prób ich opisania, rekonstrukcji, tj. po uruchomieniu kolejnego, trzeciego procesu w porządku badań archeologicznych - zwanego procesem poznawczym, badawczym, również źródłoznawczym. Podczas tego procesu odbywa się «kreowanie epistemologiczne», w wyniku którego obiekt staje się źródłem" - czyli źródłem informacji dla badacza (por. Tabaczyński, 2000, s. 117; 2012a, s. 582; 2012b, s. 739-740). 
cmentarzy wojennych teoretycznie podlegających ustawowo bezterminowej opiece), w centralnej Polsce, na omawianym w niniejszym artykule obszarze, w znacznej mierze zostały zapomniane i zaniedbane.

Poszukiwanie odpowiedzi na pytania o specyfikę postaw miejscowej ludności wobec żołnierzy Wielkiej Wojny, w tym do poległych żołnierzy, którzy spoczęli na terenach pobitewnych $\mathrm{w}$ rejonie Rawki i Bzury, nie jest proste, ani też zagadnienia te nie zostały wyczerpane. Nawet w odniesieniu do konkretnego wycinka obszaru trudno wskazać jednoznaczną odpowiedź na pytanie o typowe przejawy i wysuwać sugestie co do uwarunkowań stosunku ludności cywilnej do żołnierzy poległych w latach 1914-1915 i ewentualne długie trwanie tych postaw. Istotne w ich kształtowaniu były czynniki o charakterze pragmatycznym (np. obawa ludności cywilnej przed epidemią), kulturowo-społecznym (kogo mieszkańcy ziem nad Rawką i Bzurą uznawali za „swoich”, kogo za „obcych”), także ogólnoludzkim, humanitarnym, religijnym (imperatyw spokoju zmarłych, godnego grzebania ich szczątków).

Stawiamy tezę, że do ukształtowania się i trwania tych postaw przyczyniły się, obok innych czynników, również wymagających pogłębionych studiów - doświadczenia miejscowej ludności z czasu wojny i powojnia. Wojna wprowadziła przemoc, która wraz z dziesiątkami tysięcy żołnierzy zawitała do spokojnych wsi i miasteczek na Równinie Łowicko-Błońskiej w grudniu 1915 roku i panowała tam aż do lipca 1915 roku. Przerażenie budziła „nowa broń” masowego rażenia, jakiej użyła kilkakrotnie na tym odcinku frontu armia niemiecka - były to pociski gazowe i gazy bojowe zastosowane w formie ataków falowych. Jej charakter, skrajnie niehumanitarny, potęgował niechęć wobec Niemców i współczucie dla Rosjan, którzy zaskoczeni nową, nieznaną sobie bronią, nie byli w stanie się przed nią uchronić ${ }^{20}$. Strach przed wojskowymi władzami, utrata dobytku i poczucia bezpieczeństwa, lęk przed zarazą, choroby i cierpienia, śmierć bliskich, skrajnie trudne warunki codzienności wojennej i przez wiele lat po wojnie - tego typu traumatyczne doświadczenia warunkowały postawy miejscowej ludności wobec żołnierzy i wobec ich grobów, a także wywarły trwałe następstwa.

Podstawę takiej diagnozy stanowią źródła pisane z czasu wojny i powojnia, zebrane dane etnologiczne/antropologiczne oraz dane archeologiczne i teledetekcyjne (por. Zalewska, Kiarszys, 2017; Zalewska, Cyngot, 2017; Zalewska, 2019b; Zalewska, Czarnecki, Kiarszys, 2019). Z udziałem tych źródeł i danych można wskazać i starać się zrozumieć różne, nietworzące (na razie) spójnego obrazu doraźne i dalekosiężne przejawy postaw miejscowej ludności cywilnej wobec poległych Wielkiej Wojny. Postrzegamy je jako istotną determinantę obecnego stanu rzeczy, w tym kondycji materialnych śladów tej wojny. Powodów głębokiej niechęci wobec nich, przejawiającej się przez liczne dążenia do ich zatarcia, można upatrywać m.in. w zjawisku poczucia „obcości” poległych, ich enigmatyczności (niepoliczalności) i anonimowości (ich śmierci), a także rozczłonkowania ciał poległych (ich zdehumanizowania),

${ }^{20}$ O użyciu pod Bolimowem broni chemicznej zob.: Kaliński, 2015; Zalewska, 2016, 2019b; Zalewska, Czarnecki, 2016. 
pozostających w różnym stanie zachowania i znajdujących się w rozproszeniu w licznych przypadkowych miejscach. Przyczyniały się do tego również ekshumacje, dokonywane nie dość starannie, aby można było objęte nimi miejsca uznać za „uwolnione” od pozostałości szczątków ludzkich.

Co szczególnie warte podkreślenia, trudno za przyczynę zaniedbania cmentarzy wojennych i zapomnienia o nich uznać w badanym tu przypadku czas, jaki upłynął od omawianych wydarzeń. Doświadczenie tego rodzaju pozostawiać po sobie musi niezatarty, choć niechciany ślad, także w psychice świadków. Wydaje się, że tę sytuację najlepiej diagnozuje i podsumowuje określenie ,traumatyczna niepamięć” - użyte do analizy literatury okresu powojennego, mierzącej się z tematyką Wielkiej Wojny jako z historyczną traumą, z obecną w niej dialektyką pamięci i zapomnienia (Szczepan, 2014).

Sądzimy, że większe znaczenie niż przynależność poległych do jednej ze stron konfliktu miały sposoby postępowania ze zmarłymi przyjęte w obu walczących armiach, w tym tworzenie cmentarzy i mogił wojennych, które stanowiły wyraźne miejsca w krajobrazie pola bitwy. Wydaje się też, że decydującą rolę w procesach związanych z odnoszeniem się miejscowej ludności do miejsc spoczynku żołnierzy odegrały ogromne masy poległych. Należy przy tym pamiętać, że walki nad Rawką i Bzurą toczyły się na początku wojny, kiedy reguły postępowania z poległymi żołnierzami dopiero były wypracowywane, walki się toczyły, a służby grobownicze znajdowały się w stadium organizacji i nie zawsze właściwie radziły sobie z pochówkami ogromnych ilości ciał (por. Schubert, 2011). Zwłaszcza wczesne etapy działań grobownictwa wojennego zdeterminowały początkowo pełne lęku, a z czasem niechęci postawy ludności, mające dalekosiężny wpływ na kondycję tych miejsc.

Wnioski płynące $\mathrm{z}$ analiz archiwaliów prowadzą do dostrzeżenia pewnego paradoksu - im liczniejsze ofiary wojny, tym trudniejsze opanowanie, ustalenie, uporządkowanie pamięci o nich, podobnie jak i przestrzeni zniszczonej działaniami wojennymi. Wyniki analiz danych archeologicznych stanowią nie tylko potwierdzenie, ale i uzupełnienie treści wynikających ze źródeł pisanych. Są one ponadto prowokacją do zadawania kolejnych pytań odnoszących się do czynników (również tych z domeny materialności), które kształtowały i po dziś dzień kształtują postawy wobec śladów Wielkiej Wojny, także takich jak pozostałe po niej miejsca spoczynku poległych.

Masowa i trwająca latami trauma ludzi w miejscach doświadczonych Wielką Wojną nie została dotychczas dostatecznie rozpoznana dla frontu wschodniego, w tym dla centralnej Polski. Tego rodzaju doświadczenie czasu wojny ma to do siebie, że jest długotrwałe, i - co znajduje liczne uzasadnienia psychologiczne - może być, nawet nieświadomie i bezwiednie, przekazywane z pokolenia na pokolenie. Nie było ono (w świetle naszej wiedzy) przedmiotem szczególnej uwagi socjologów, historyków, kulturoznawców lub archeologów. Jest to temat zasługujący na odrębne omówienie.

Jednym z przejawów woli kreowania kolejnych wersji historii (narracji o) rerum gestarum składających się na trudne dziedzictwo frontu wschodniego Wielkiej Wojny w centralnej Polsce, jest rosnąca w ostatnich latach otwartość mieszkańców miejsc doświadczonych przez wydarzenia z lat 1914-1915 na poznawanie historii i dziedzic- 
twa swych „małych ojczyzn”. Proces ten można interpretować jako przezwyciężanie $\mathrm{z}$ jednej strony niewiedzy, z drugiej obciążenia trwającego od tamtego czasu, które powodowało pozostawanie miejscowych świadków wydarzeń i ich potomków w stanie traumy, często nieuświadamianej. Sprzyja temu upowszechnianie wiedzy na temat dziedzictwa kulturowego i jego wartości również w odniesieniu do dziedzictwa konfliktów zbrojnych XX w., w tym z I wojny światowej, m.in. przez upublicznianie wyników badań na temat założeń, uwarunkowań i efektów podnoszenia do rangi zabytków archeologicznych znalezisk stanowiących materialne ślady I wojny światowej na forum lokalnym i krajowym. Między innymi do realizacji tego celu chciałyśmy się przyczynić niniejszym artykułem.

Za oznakę procesu wychodzenia z trwającej już ponad wiek powojennej traumy można uznać stopniowy wzrost oddolnej troski o dziedzictwo Wielkiej Wojny, w tym mogiły i cmentarze wojenne obecne nad Rawką i Bzurą. Przejawia się ona w porządkowaniu tych obiektów, obchodach rocznic związanych z wydarzeniami wojennymi, uczestniczeniu w pochówkach szczątków poległych żołnierzy odnajdywanych podczas prac inwestycyjnych oraz badań archeologicznych (por. szerzej na ten temat Zalewska, 2019a, s. 416 i n.). Również rośnie nadzieja na upowszechnienie postaw cechujących się wrażliwością historyczną, wolą zrozumienia wartości trudnego dziedzictwa, empatią, otwartością na traktowanie miejsc spoczynku żołnierzy poległych, niezależnie od ich przynależności wojskowej i czynów wojennych, ,jak ludzi”, a materialnych śladów Wielkiej Wojny jako przestróg - elementów historii (narracji o) rerum gestarum - niosących znaczące wartości naukowe, historyczne i społeczne dla współczesności i przyszłości.

Zawarte w niniejszym artykule refleksje i wnioski składają się na realizację projektu „Archeologia Frontu Wschodniego Wielkiej Wojny i dziedzictwo konfliktów zbrojnych jako wyzwanie" (nr. 4445/20/FPK/NID). Dofinansowano ze środków Ministra Kultury i Dziedzictwa Narodowego pochodzących z Funduszu Promocji Kultury, uzyskanych $\mathrm{z}$ dopłat ustanowionych w grach objętych monopolem państwa, zgodnie z art. 80 ust. 1 ustawy z dnia 19 listopada 2009 roku o grach hazardowych.

\section{BIBLIOGRAFIA}

Białek, E.

1939 Wspomnienia z pierwszej ofensywy na Warszawę. „,Gronie” Kwartalnik Poświęcony Sprawom Żywiecczyzny, r. 2, kwiecień-wrzesień, 2-3(6-7), 60-65.

Borzyszkowski, J., Olbracht-Prądzyński, C.

1996 Doświadczenie wojny w świetle wspomnień Pomorzan. W: M. Wojciechowski (red.), Społeczeństwo polskie na ziemiach pod panowaniem pruskim w okresie I wojny światowej (1914-1918). Zbiór studiów (s. 7-25). Toruń: Uniwersytet Mikołaja Kopernika.

Brudek, P.

2010 Rosja w propagandzie niemieckiej podczas I wojny światowej w świetle „Deutsche Warschauer Zeitung”. Warszawa: Wydawnictwo Neriton, Instytut Historii PAN. 
Dowbor-Muśnicki, J.

2013 Moje wspomnienia. Poznań: Zysk i S-ka.

Falis, A., Jakubczak, M., Klęczar, B., Myśliwiec, T., Szymczak, N.

2015 Sprawozdanie z badań archeologicznych przeprowadzonych w miejscowości Bolimowska Wieś (nr ewid. działek: 135/2 oraz 135/1) [maszynopis, s. 17], Warszawa.

Gebhardt, O. Dr.

1933 Geschichte des Res.-Inf.-Regts. Nr. 228, Dritter Teil, Von Brzeziny bis Bolimow [b.m.w.].

Górny, M.

2014 Niezbyt wielka wojna. Herito. Dziedzictwo, kultura, współczesność, 16, 36-43.

Hulka-Laskowski, P.

1934 Mój Żyrardów. Z dziejów polskiego miasta i z życia pisarza. Warszawa: Wydawnictwo Jana Przeworskiego.

Ihnatowicz, I.

1967 Vademecum do badań nad historia XIX i XX wieku, t. 1. Warszawa: Wydawnictwo Naukowe PWN.

Jakubczak, M., Leloch, M., Myśliwiec, T., Radziszewska, K., Szarlip, A.

2017 Sprawozdanie z badań archeologicznych na stanowisku nr 19 w miejscowości Wola Szydlowiecka [maszynopis, s. 17.]. Warszawa.

Kaliński, S.

2013 Łowicz: w poszukiwaniu miasta etapowego. Odkrywca, 3(170), 52-57.

2015 Bolimów 1915. Warszawa: Wydawnictwo Bellona.

2019a „Dziś wieczorem idziemy do okopów”. Niemiecka poczta polowa (Feldpost) w bitwie nad Rawką i Bzurą. W: A. I. Zalewska (red.), Archeologiczne przywracanie pamięci o Wielkiej Wojnie w rejonie Rawki i Bzury (1914-1915) (s. 299-314). Warszawa: Instytut Archeologii i Etnologii PAN.

2019b Od powołania do listy strat. Żołnierze armii niemieckiej i rosyjskiej w bitwie nad Rawką i Bzurą. W: A. I. Zalewska (red.), Archeologiczne przywracanie pamięci o Wielkiej Wojnie w rejonie Rawki i Bzury (1914-1915) (s. 43-80). Warszawa: Instytut Archeologii i Etnologii PAN.

Karczewska, M.

2019 Cmentarze Wielkiej Wojny na terenie pola bitwy nad Rawką i Bzurą na podstawie materiałów niemieckiego Ministerstwa Spraw Zagranicznych oraz Volksbund Deutsche Kriegsgräberfürsorge e.V. z lat 1923-1939. W: A. I. Zalewska (red.), Archeologiczne przywracanie pamięci o Wielkiej Wojnie w rejonie Rawki i Bzury (1914-1915) (s. 353-385). Warszawa: Instytut Archeologii i Etnologii PAN.

Kulik, M.

2008 Polacy wśród wyższych oficerów armii rosyjskiej Warszawskiego Okręgu Wojskowego 1865-1914. Warszawa: Wydawnictwo Neriton.

2012 Polacy w jednostkach Rosyjskiej Gwardii w Warszawie na przełomie XIX i XX wieku. Niepodległość i Pamięć, 1-4(37-40), 37-53.

Luba, I., Wawer, E. P.

2017 Władysław Strzemiński-zawsze w awangardzie. Rekonstrukcja nieznanej biografii 18931917. Łódź: Muzeum Sztuki.

Marchewka, J., Konopka, T., Szarlip-Myśliwiec, A., Mucha, N.

2019a Szczątki kostne poległych znad Rawki i Bzury. Wyniki analiz antropologicznych i medyczno-sądowych. W: A. I. Zalewska (red.), Archeologiczne przywracanie pamięci o Wielkiej Wojnie w rejonie Rawki i Bzury (1914-1915) (s. 325-341). Warszawa: Instytut Archeologii i Etnologii PAN.

Marchewka, J., Bełka, Z., Wardas-Lasoń, M.

2019b Badania składu izotopowego strontu i składu pierwiastkowego szczątków żołnierzy poległych podczas I wojny światowej (1914-1915) nad Rawką i Bzurą. W: A. I. Zalewska 
(red.), Archeologiczne przywracanie pamięci o Wielkiej Wojnie w rejonie Rawki i Bzury (1914-1915) (s. 343-348). Warszawa: Instytut Archeologii i Etnologii PAN.

Ogórek, B.

2018 Niezatarte piętno? Wplyw I wojny światowej na ludność Miasta Krakowa. Kraków: Universitas.

Rohkohl, W. 1923

Schubert, J.

2011

Reserve Infanterie-Regiment 226. Oldenburg - Berlin: Stalling.

Szczepan, A.

2014 Traumatyczna niepamięć: doświadczenie Wielkiej Wojny w polskiej literaturze dwudziestolecia. Przeglad Kulturoznawczy, 4(22), 411-426.

Tabaczyński, S.

1987 Archeologia średniowieczna. Problemy, źródła, metody, cele badawcze. Wrocław - Warszawa - Kraków - Gdańsk - Łódź: Zakład Narodowy im. Ossolińskich, Wydawnictwo PAN.

1994 Wprowadzenie. W: J. Lech (red.), Ocena stanu archeologii w Polsce. Materiaty informacyjne. Warszawa: Komitet Nauk Pra- i Protohistorycznych Wydziału I PAN.

2000 Rzeczowe korelaty kultury: znaczenie pojęcia i problemy interpretacyjne $\mathrm{w}$ badaniach archeologicznych. W: S. Tabaczyński (red.), Kultury archeologiczne a rzeczywistość dziejowa (s. 113-134). Warszawa: Wydawnictwo Naukowe PWN.

2012a Kultura i kultury. W: S. Tabaczyński, A. Marciniak, D. Cyngot, A. Zalewska (red.), Przeszłość społeczna. Próba konceptualizacji (s. 571-604). Poznań: Wydawnictwo Poznańskie.

2012b Socjologia pradziejów. Zarys problematyki. W: S. Tabaczyński, A. Marciniak, D. Cyngot, A. Zalewska (red.), Przeszłość społeczna. Próba konceptualizacji (s. 732-769). Poznań: Wydawnictwo Poznańskie.

Tarczyński, W.

2015 Nie wybiła godzina wybawienia z otchtani nieszczęść... Kronika dziejów Łowicza Władysława Tarczyńskiego. Warszawa: Naczelna Dyrekcja Archiwów Państwowych.

Topolski, J.

2016 Teoretyczne problemy wiedzy historycznej. Antologia tekstów. Poznań: Polskie Towarzystwo Naukowe. Wydawnictwo Nauka i Innowacje.

Washburn, S.

1915 Field Notes From The Russian Front. London: Melrose.

Wojtylak, M.

1997 Bój pod Bednarami. Masovia Mater, 17, 1 i 4.

2015 Władysław Tarczyński i jego kronika. W: Nie wybiła godzina wybawienia z otchłani nieszczęść... Kronika dziejów Łowicza Władysława Tarczyńskiego (s. 7-35). Warszawa: Naczelna Dyrekcja Archiwów Państwowych.

W.T.

1918 Polacy w armii rosyjskiej. Wiarus, 6, 130-132.

Zalewska, A. I.

2009 O (nie)obecności naszych źródet. W: W. Dzieduszycki, J. Wrzesiński (red.), Metody, źródła, dokumentacja. Funeralia Lednickie spotkanie, t. 11 (s. 13-19). Poznań: Stowarzyszenie Naukowe Archeologów Polskich.

2013 Roadside Lessons of Historicity. The Roles and the Meanings of the Material Points of References to The Great War and in Shaping Historical Sensitivity and Awareness. Sensus Historiae, 13, 69-85.

2016 The 'Gas-scape' on the Eastern Front, Poland (1914-2014): Exploring the Material and Digital Landscapes and Remembering Those 'Twice-Killed'. W: B. Stichelbaut, D. Cowley (red.), Conflict landscapes and archaeology from above (s. 147-165). London: Routledge. 
2017 Archeologia czasów współczesnych i (nie)moc działania materialnych śladów Wielkiej Wojny w Polsce (Archaeology of the contemporaneous times and the power(lessness) of physical traces of the Great War in Poland). Ochrona Zabytków, 2, 47-77.

Zalewska, A. I. (red.)

2019a Archeologiczne Przywracanie pamięci o Wielkiej Wojnie w rejonie Rawki i Bzury (19141915). Warszawa: Instytut Archeologii i Etnologii PAN.

2019b Archaeology of the Eastern Front of World War I. Summary/Archeologia frontu wschodniego I wojny światowej. Podsumowanie. W: A. I. Zalewska (red.), Archeologiczne Przywracanie pamięci o Wielkiej Wojnie w rejonie Rawki i Bzury (1914-1915) (s. 409-420), Warszawa: Instytut Archeologii i Etnologii PAN.

2019c Historia użycia przez armię niemiecką broni masowego rażenia (Massenwirkung) w rejonie Rawki i Bzury w styczniu 1915 roku. W: A. I. Zalewska (red.), Archeologiczne Przywracanie pamięci o Wielkiej Wojnie w rejonie Rawki i Bzury (1914-1915) (s. 99-112). Warszawa: Instytut Archeologii i Etnologii PAN.

Zalewska, A. I., Cyngot, D.

2017 Problem zanikania pamięci o miejscach spoczynku żołnierzy poległych w walkach nad Rawką i Bzurą w latach 1914-1915. Acta Universitatis Lodziensis. Folia Archaeologica, 32, 119-156.

2019 Problem masowej śmierci i (nie)obecności miejsc spoczynku żołnierzy poległych w rejonie Rawki i Bzury w latach 1914-1915. W: A. I. Zalewska (red.), Archeologiczne przywracanie pamięci o Wielkiej Wojnie w rejonie Rawki i Bzury (1914-1915) (s. 317-324). Warszawa: Instytut Archeologii i Etnologii PAN.

Zalewska, A. I., Cyngot, D., Czarnecki, J., Kiarszys, G.

2018a Czystko ludzka sprawa? Archeologiczne przywracanie pamięci o trudnej przeszłości przez tropienie naturo-kulturowych przemian cmentarzy wojennych. Folia Praehistorica Posnaniensia, 23, 189-229.

2018b Miejsca spoczynku poległych w toku Wielkiej Wojny nad Rawką i Bzurą - ich zaistnienie, trwanie i zanik... oraz poznanie i ochrona. W: M. Karczewska (red.), Cmentarze wojenne I wojny światowej po stuleciu. Stan badań i ochrony (s. 71-102). Białystok: Ośrodek Badań Europy Środkowo-Wschodniej.

Zalewska, A. I., Czarnecki, J.

2016 Ślady i świadectwa Wielkiej Wojny nad Rawka i Bzura. Warszawa: Fundacja Przydrożne Lekcje Historii.

2019 Zastój na całej linii. Historia przejścia od wojny manewrowej do pozycyjnej na przyczółku bolimowskim (1914/1915). W: A. I. Zalewska (red.), Archeologiczne przywracanie pamięci o Wielkiej Wojnie w rejonie Rawki i Bzury (1914-1915) (s. 27-42). Warszawa: Instytut Archeologii i Etnologii PAN.

Zalewska, A. I., Czarnecki, J., Kiarszys, G.

2019 Krajobraz Wielkiej Wojny. Front nad Rawka i Bzura (1914-1915) w świetle teledetekcji archeologicznej i źródet historycznych. Warszawa: Fundacja Przydrożne Lekcje Historii.

Zalewska, A. I., Kiarszys, G.

2017 Absent Presence of Great War Cemeteries in the Municipality of Bolimów, Central Poland. W: A. Zalewska, J. M. Scott, G. Kiarszys (red.), The Materiality of Troubled Pasts. Archaeologies of Conflicts and Wars (s. 55-81). Warszawa - Szczecin: Fundacja Przydrożne Lekcje Historii.

2019 Cmentarze i mogiły wojenne zlokalizowane w wyniku Archeologicznego Przywracania Pamięci o Wielkiej Wojnie w aktualnych granicach gmin Bolimów, Nieborów, Nowa Sucha i Wiskitki. W: A. I. Zalewska (red.), Archeologiczne przywracanie pamięci o Wielkiej Wojnie w rejonie Rawki i Bzury (1914-1915) (s. 403-408). Warszawa: Instytut Archeologii i Etnologii PAN. 


\title{
ARCHIWALIA
}

Archiwum Państwowe w Warszawie, Oddział Łowicz, Akta Gminy Bolimów

APW OŁ, AGBol nr 58 (Sprawa cmentarzy wojskowych, 1922), k. 3.

APW OŁ, AGBol nr 186 (Sprawy bezpieczeństwa, po II wojnie światowej), k. 24.

Archiwum Państwowe w Warszawie, Oddział Łowicz, Akta Magistratu Miasta Łowicza

APW OŁ, AMMŁ nr 18 (Korespondencja dot. stacjonowania wojsk niemieckich na terenie m. Łowicza 1915-1916).

APW OŁ, AMMŁ nr 19 [Sprawy dot. stacjonowania wojsk niemieckich w Łowiczu, 1916].

APW OŁ, AMMŁ nr 24 (Sprawy handlowe 1915-1917).

APW OŁ, AMMŁ nr 26 (Sekwestracja materiałów wojennych 1915-1917).

APW OŁ, AMMŁ nr 27 (Rozdziat mąki i otrębów 1915-1917).

APW OŁ, AMMŁ nr 28 [Oferty reklamowe firm, głównie niemieckich, 1915-1917].

APW OŁ, AMMŁ nr 32 (Sprawy cmentarza, 1915-1916 r.), k. 15, 19.

APW OŁ, AMMŁ nr 517 [m.in. Sprawy cmentarzy, ekshumacji, pomników, 1922 r.], k. 63.

Archiwum Państwowe w Warszawie, Oddział Grodzisk Mazowiecki, Akta Gminy Żyrardów-Wiskitki

APW OGM, AGŻW nr 1268 [Spisy poborowych za 1914 r.].

APW OGM, AGŻW nr 1281 [Korespondencja dot. Rezerwistów, 1914, Paszporty rezerwistów].

APW OGM, AGŻW nr 1319 [Korespondencja dot. centralnych zbiórek rezerwistów, 1914 r.].

APW OGM, AGŻW nr 1323 [Spisy rowerów w Żyrardowie, 1914, przekazanych do gminy].

APW OGM, AGŻW nr1324 [Sprawy rodzin rezerwistów, 1914].

APW OGM, AGŻW nr1325 (O wojnie z Niemcami i Austria i nastrojach ludności w związku z ta wojna, 1914), k. 5, 39-40, 56.

APW OGM, AGŻW nr 1326 [Podwody do budowania fortyfikacji, 1914].

APW OGM, AGŻW nr 1328 [Rejestry Niemców i Austriaków w gminie Żyrardów, 1914].

APW OGM, AGŻW nr1329 [Spisy niemieckich i austriackich poddanych w gminie Żyrardów, 1914].

APW OGM, AGŻW nr 1330 [Powołania piechoty, pow. błoński, 1914].

APW OGM, AGŻW nr1335 [Wykaz osób wyznania prawosławnego w gminie Żyrardów, 1915].

APW OGM, AGŻW nr 1336 [Sprawy kwater dla wojska, 1914-1915].

APW OGM, AGŻW nr1339 (Ziemia pod cmentarz, 1915), k. 2, 15.

HStAS - Hauptstaatsarchiv Stuttgart (archiwum w Stuttgarcie): HStAS M33/2 Bu 89.

Kuzniecow A. [Кузнецов А.]

1915 Фронтовойдневник рядового Андрея Кузнецова с 1914 nо 1915 (maszynopis dostępny w archiwum projektu APP, brak paginacji. Tłumaczenie fragmentów wybranych przez A. Zalewską autorstwa A. Czapiuk).

RGVIA [РГВИА] - Российский государственный военно-исторический архив (Rossijskij gosudarstvennyj voenno-istoričeskij arhiv): Фонд 2019 О.1 д. 73.

\section{INFLUENCE OF THE MILITARY HISTORICAL EVENTS (RES GESTAE) AND REPORTS ABOUT THEM (HISTORY RERUM GESTARUM) ON THE CONDITION OF MATERIAL REMAINS OF THESE EVENTS. CASE STUDY OF THE HERITAGE OF ARMED CONFLICTS AS A COGNITIVE, SOCIAL CHALLENGE}

\author{
Sum mary
}

Loss of property, extremely difficult conditions of everyday life during and for many years after the war, illnesses and suffering, fear of military authorities and soldiers, fear of epidemic factors and 
infectious diseases, death of loved ones - these types of traumatic experiences conditioned the attitude of the local population towards soldiers and had consequences that last till today. We observe relatively weak interest in material traces of Great War and almost complete lack of care over the remaining material relics after them, including graves and war cemeteries left after massive death in the context of the former battlefield. We perceive it as closely related to the "traumatic oblivion", and to the limited representation in Polish historiography and small knowledge about them.

We focus our attention here - as one of the possible aspects of all issues related to the Great War. It is - on the ratio of the local population to soldiers fighting in the Russian and German armies, alive and killed. We analyze the translation of this relationship into the material and cultural dimensions - traces that remained in central Poland after the Great War. We try to recognize through archival data and document the current condition of the material heritage of the Great War in the area of a specific battlefield, and over time of the former battlefield (battlefields) over Rawka and Bzura, captured through archaeological research. We try to connect (to find tangents) fragmentary images emerging from archival documents and war diaries with their representations (material and discursive) in the present.

The purpose of our investigation is to comprehensively identify the determinants of the condition of material traces remaining after the battles fought during World War I in 1914-1915 on the one of the sections of the Eastern Front in today's Poland, the so-called Bolimów bridgehead. We tried to understand the reasons for this state of affairs, observing the source-forming process, including observing a kind of "break in continuity" between the world of reality (objectively occurring facts and events), and the world of knowledge and memory (re-presented in descriptions of these facts and events, recognized and valued in cause-and-effect sequences as histories about the events of 1914-1915 in the Łowicz-Błonie Plain, belonging to the Middle Mazovian Lowland). The resting places of fallen soldiers are treated as the focal.

Focusing on the material and discursive dimensions, we analyze the relationship and translation of the primary (res gestae) into the consequential/secondary (rerum gestarum histories and narrations) as two different ontological orders, using the methodological guidelines of Professor Stanisław Tabaczyński. Such theoretical orientation in conjunction with using the methods of historical archaeology, archaeology of contemporary past, memory studies, history, etc., prompted us to attempt to understand the reasons for the contemporaneous state of affairs of the Great War heritage in Central Poland. It can contribute to deeper understanding of the value of a difficult heritage (including resting places of fallen soldiers) and might cause increased involvement or at least greater openness in their in situ protection. 